\title{
CAVE FILL IN THE ČRNOTIČE QUARRY, SW SLOVENIA: \\ PALAEOMAGNETIC, MINERALOGICAL AND GEOCHEMICAL STUDY
}

\section{PALEOMAGNETNE, MINERALOŠKE IN GEOKEMIČNE ANALIZE JAMSKIH SEDIMENTOV V KAMNOLOMU ČRNOTIČE}

PAVEL BOSÁK ${ }^{1} \&$ ANDREJ MIHEVC ${ }^{2} \&$ PETR PRUNER $^{1} \&$ KAREL MELKA ${ }^{1} \&$ DANIELA VENHODOVÁ ${ }^{1} \&$ ANNA LANGROVÁ $^{1}$

${ }^{1}$ Institute of Geology, Academy of Sciences of the Czech Republic, Rozvojová 135, CZ-165 02 PRAHA, CZECH REPUBLIC

${ }^{2}$ Karst Research Institute, Slovenian Academy of Sciences and Arts, Titov trg 2, SI-6230 POSTOJNA, SLOVENIA 


\section{Pavel Bosák \& Andrej Mihevc \& Petr Pruner \& Karel Melka \& Daniela Venhodová \& Anna Langrová: Paleomagnetne, mineraloške in geokemične analize jamskih sedimentov v kamnolomu Črnotiče}

V kamnolomu Črnotiče je bila izkopana s sedimenti in sigo z zapolnjena jama. Analiziran je bil 1,75 m visok del zapolnitve. Profil je sestavljen iz pasovite karbonatne kamnine z interkalacijami rdečih ilovic. Te so se odložile na erozijsko/korozijsko površino starejše, že močno prekristaljene sige. Pasovita in laminirana karbonatna kamnina profila je sestavljena iz prekristaljenega kalcilutita ter je podobna sladkovodnemu apnencu. Značilna laminiranost nakazuje nastanek iz bogatih organskih filmov. Rdeče ilovice sestavljajo kremen, smektit, vermikulit, gibbsit, pM kaolinit, goethit, atanas, rutil, haematit, kalcit, sljude in glinenec. Vsebujejo tudi pelete $\mathrm{Z}$ več Mn hidroksioksidov. Rdeče ilovice so ostanki preperevanja, odloženi v Z vodo zasičenem okolju. Za v profilu vzete vzorce so značilne srednje do visoke vrednosti $J_{n}$ kar je posledica velike količine železovih mineralov. Srednja paleomagnetna smer je za skupino normalnih paleomagnetnih polaritet enaka $\mathrm{D}=10.6^{\circ}$; $\mathrm{I}=55.0^{\circ}$, za skupino reverznih polaritet pa $\mathrm{D}=173.0^{\circ} ; \mathrm{I}=-31.3^{\circ}$. Zgornji del profila kaže reverzno paleomagnetno smer, ki jo prekinjata dve normalni magnetozoni. Sodeč po razporeditvi posameznih magnetozon sklepamo, da je vrh najvišje normalno polarizirane cone primerljiv z dogodkom Olduvai (1.76/1.79 Ma) kot najmlajšo možnostjo, ostali del profila pa je lahko le starejši.

Ključne besede: magnetostratigrafija, fosilna jama, terra rossa, siga, Kras, Slovenija.

\section{Abstract}

UDC: $550.3: 551.44(497.4)$

631.445.6:551.44(497.4)

Pavel Bosák \& Andrej Mihevc \& Petr Pruner \& Karel Melka \& Daniela Venhodová \& Anna Langrová: Cave fill in the Črnotiče Quarry, SW Slovenia: palaeomagnetic, mineralogical and geochemical study

A fossil cave, filled with cave sediments was open in the Črnotiče Quarry. An about $1.75 \mathrm{~m}$ high section was analysed. Profile consists of banded carbonate rocks intercalated by red clays which was deposited on corroded/eroded surface of older speleothems. Banded and laminated carbonate rocks are composed of recrystallized calcilutite resemble freshwater limestones. Characteristics of lamination could indicate its origin from organic-rich films. Red clays are composed of quartz, smectite, vermiculite, gibbsite, pM kaolinite, goethite, anatase, rutile, haematite, calcite, micas and feldspar. They contain pellets with Mn hydroxyoxides. That red clays are weathering products redeposited in water-saturated environment. Samples are characterised by intermediate up to high magnetic values of $J_{n}$ which is caused by the presence of high amount of Fe-minerals. Mean palaeomagnetic directions are for the group of normal palaeomagnetic polarity equal to $\mathrm{D}=10.6^{\circ} ; \mathrm{I}=$ $55.0^{\circ}$, and for the group of reverse polarity than $\mathrm{D}=173.0^{\circ} ; \mathrm{I}=-31.3^{\circ}$. The top part of the profile shows reverse palaeomagnetic direction interrupted by two normal magnetised zones. According to the arrangement of individual magnetozones we assume, that the top of the highest normal polarised magnetozone could be correlated with the Olduvai event $(1.76 / 1.79 \mathrm{Ma})$ as the youngest possibility, and therefore the rest of profile must be older.

Key words: magnetostratigraphy, fossil cave, terra rossa, speleothem, Kras, Slovenia. 


\section{SITE LOCATION}

The Črnotiče Quarry is situated on the western side of the Podgorski karst, a widely extended levelled plateau at the foothills of the Slavnik Mt. (Fig. 1). The plateau is built of Palaeogene limestones and narrow zones of flysch. Shallow oblong depressions were formed on the flysch. The quarry is located near the morphologically expressive margin of the karst plateau, which descends in a sharp flexure to the Rižana valley (Fig. 2).

The location of the quarry is $45^{\circ} 33^{\prime} 57^{\prime \prime} \mathrm{N}, 13^{\circ} 52^{\prime} 48^{\prime \prime} \mathrm{E}$. The altitude of the levelled surface is at about $440 \mathrm{~m}$ a.s.l. The quarry is about $9 \mathrm{~km}$ from the Adriatic coast in Koper Bay.

The quarry occupies an area of 300 by $300 \mathrm{~m}$ and it has a depth of about $40 \mathrm{~m}$. The samples for palaeomagnetic and other analyses were taken on the western side of the quarry from the upper part of a fossil cave. The cave was discovered during quarry operations in 1997, and in 1999 it was completely destroyed by the quarry exploitation.

\section{GEOLOGICAL FRAMEWORK}

The Podgorski karst is built of Palaeocene and Eocene Alveolinid and Nummulitic limestones, and Eocene flysch sandstones and marls. Due to strong pressures in the NE - SW direction, a com-

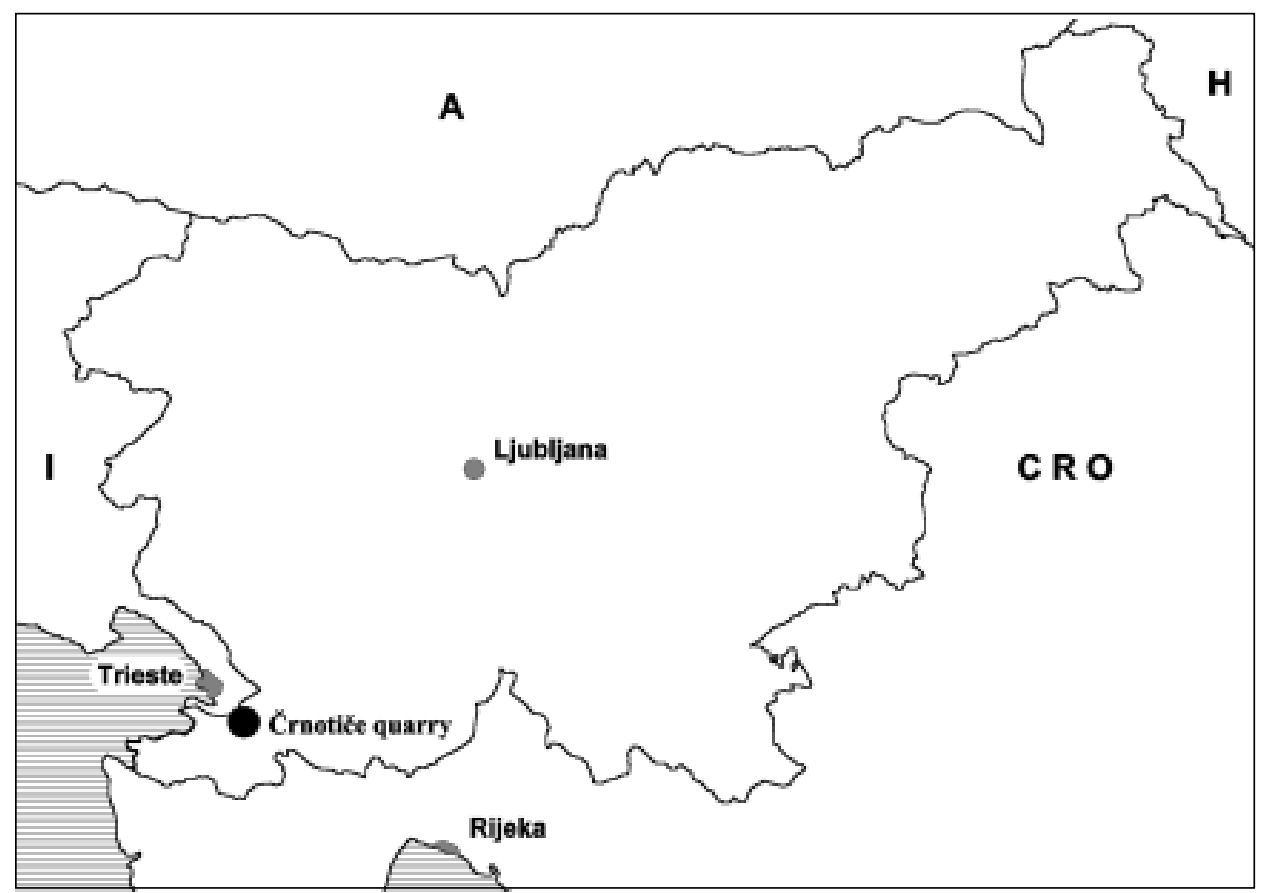

Fig. 1: Map of Slovenia with the position of the Črnotiče Quarry. 


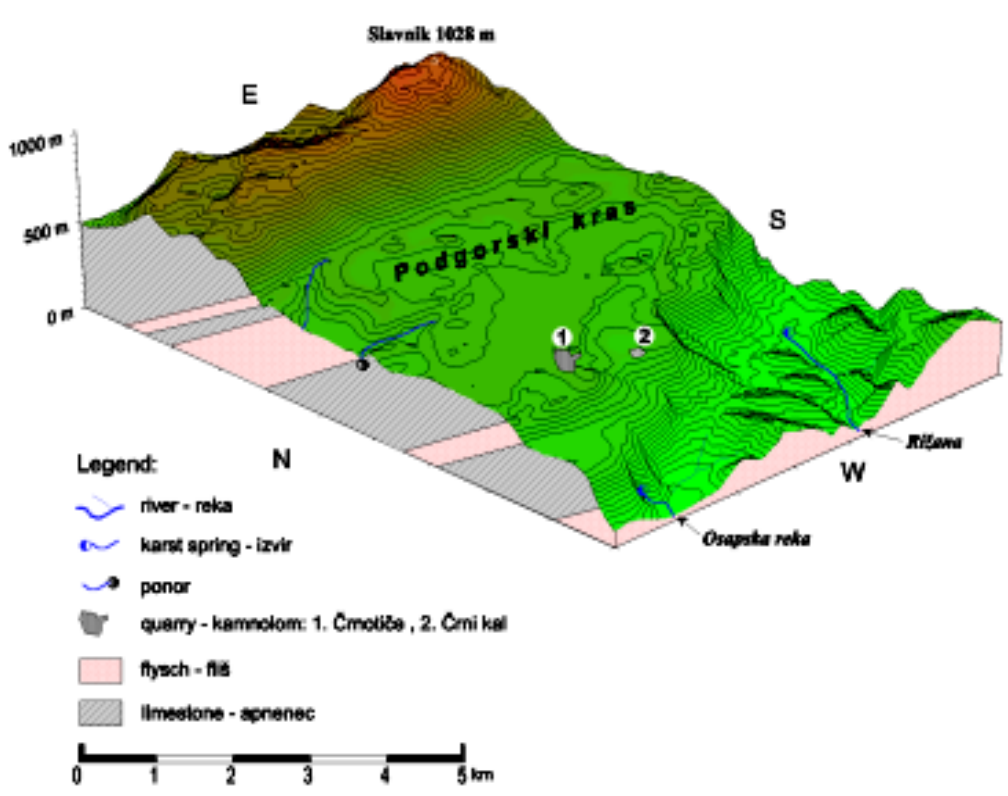

Fig. 2: The location of the Črnotiče Quarry at the western edge of the Podgorski karst plateau.

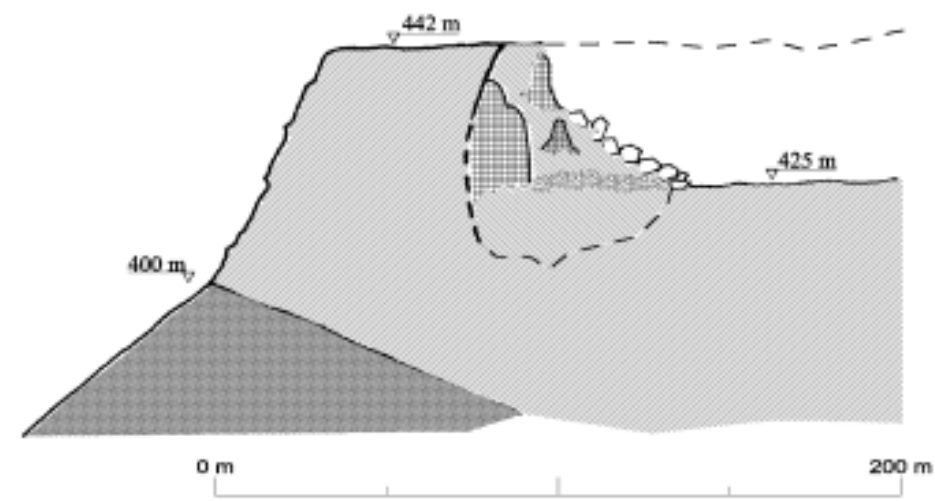

Legend

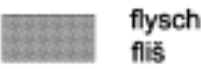

flis

clay

ilovica

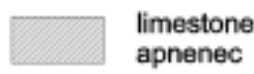

fluvial gravel prod large stalagmites veliki kapniki

Fig. 3: Schematic cross-section of the edge of the karst plateau, quarry and studied cave. 
plicated imbricated structure was formed with an alternation of flysch and limestone zones elongated in the NW $\rightarrow$ SE direction. Thrust planes dip towards the north - east ( $c f$. Placer 1981).

The Karst levelled stony surface with dolines was formed on limestones. As flysch zones were less resistant, shallow oblong valleys occur there, sometimes with sinking streams. Resistant limestones form vertical walls at their margins. On the western side the Podgorski karst plateau is connected with the flysch by the imbricated structure of the thrust margin. In this part the plateau descends by several structural steps to the depression of the Rižana valley developed on flysch.

The quarry was opened at the plateau margin in Palaeogene limestones, which were overthrust over flysch ( $c f$. Fig. 3). The tectonic contact of limestones and flysch is situated about $100 \mathrm{~m}$ to the southwest of the cave location. The thrust plane dips at the angle of about $25^{\circ}$ towards the northeast.

\section{KARST FEATURES OF THE PODGORSKI KARST}

The Podgorski karst is a karst plateau about $5 \mathrm{~km}$ wide extended in the NW-SE direction. Its surface is located at 500 to $450 \mathrm{~m}$ a.s.l. The plateau surface is levelled and dismembered only by numerous dolines. The surface is stony, covered by an unconnected coverage of thin soils of the rendzina type. The surface inclination is gentle, only some degrees.

Only small allogenic surface streams of the first or second order exist on the plateau surface flowing from the flysch zones. They sink at the carbonate/flysch contact into the limestone shales. The imbricated structure dips at an angle of about $20-30^{\circ}$ towards the north-east. In depth, the imbricated structure with alternation of limestones and flysch is not completely impervious and it is crossed by major water streams draining an extensive karst area in the direction towards springs at the coast. Water springs out from the Rižana and Osapska rivers (maximum discharge in several $\left.\mathrm{m}^{3} \cdot \mathrm{s}^{-1}\right)$ under the plateau at altitudes of 50-100 $\mathrm{m}$ a.s.l.

In all 92 caves have been known on the plateau. Twelve caves are deeper than $50 \mathrm{~m}$, and 15 are more than $100 \mathrm{~m}$ long. The deepest cave has a depth of $150 \mathrm{~m}$.

\section{Karst features in the Črnotiče and Črni Kal Quarries}

Numerous caves have been opened during operations in the Črnotiče Quarry. Most of them were completely filled by sediments. The deepest cave was opened in 1991 in the northern part of the quarry at the altitude of about $400 \mathrm{~m}$ a.s.l. It was an about $80 \mathrm{~m}$ deep shaft which widened towards the bottom. The shaft volume could be estimated as several thousands of cubic meters. The shaft was not explored.

Several shafts were opened by excavation fronts in the western part of the quarry. Again, they were filled by gravel mixed with terra rossa derived clayey sediments. Gravel filled vertical caves with stalagmites and stalactites on the walls. Broken speleothems could be often found also within gravel, as well as numerous large bones of mammals fallen down the shafts. Unfortunately, the bones have not been studied yet. The gravel was cemented into breccia in places. The breccia cement was dated by the ${ }^{230} \mathrm{Th} /{ }^{234} \mathrm{U}$ method to $211 \pm 45 \mathrm{ka}$ (datings by A. Mihevc in Speleothem Dating Laboratory, Department of Geology, Bergen University, Norway, head Prof. Stein-Erik Lauritzen).

Nearby, about $1 \mathrm{~km}$ to the $\mathrm{S}$ of the Črnotiče Quarry there is opened the Črni Kal Quarry at the altitude of about $350 \mathrm{~m}$ a.s.l. Palaeogene limestone overthrust over Eocene flysch is exploited. Horizontal caves or vertical shafts have been uncovered during quarry operations. A horizontal 
cave was discovered in 1955 on the southern side of the quarry. Palaeolithic tools and Pleistocene large mammal fauna were discovered here (Rakovec 1958; Brodar 1958). Several karst fillings and shafts are exposed in the quarry. Shafts were filled by gravel and terra rossa type of clays. Some gravels were cemented. The carbonate cement was dated by the ${ }^{230} \mathrm{Th} /{ }^{234} \mathrm{U}$ method to $143 \pm 13 \mathrm{ka}$. Three sites yielded early Biharian (Early Pleistocene) to Late Pleistocene small mammals (Aguilar et al. 1998).

Two types of caves can be observed in both quarries: (1) old horizontal caves with allogenic fluvial fill derived from flysch rocks, and (2) vertical shafts filled only by local angular gravel, bone breccia, and terra rossa type of soils.

\section{Description of studied cave}

Already before 1990, in the western part of the quarry there appeared an extensive volume of speleothems, sandy layers and clays indicating the presence of large horizontal cave choked by sediments. Some years ago, the quarry exploitation opened the cave entirely. Some calcareous cave sediments have remained in the southern quarry wall up to the present.

The cave was successively opened during several years by the progress of quarry front. Owing to strong blasting, it was not possible to contour the cave shape precisely. It was about $150 \mathrm{~m}$ long with the dip in the NW-SE direction. The opened cave represented a relic of a huge passage with the diameter of about $10 \mathrm{~m}$. Sedimentary fill was $10 \mathrm{~m}$ thick at least. In the eastern part, the passage opened up to the present surface, but in the western part the ceiling has been still preserved (Fig. 3).

The passage was entirely filled by the cave sediments deposited over the massive flowstones several meters thick. Calcareous sediments were extended up to the present surface where they were strongly disintegrated. Gravel and conglomerates were preserved and mixed up with sand and clay on several places. Poorly rounded pebbles, up to $4 \mathrm{~cm}$ across, were composed of Palaeocene limestone and flysch fragments. Laminated yellow brown clays (10YR 5/6) were present in several places. Stalagmite and stalactite fragments were present within the sediment. The upper part of the profile was composed of dominant reddish clays (2.5YR 4/8).

Samples for palaeomagnetic analyses were taken from the upper part of cave fill, about $4 \mathrm{~m}$ below the surface of the karst plateau at about $440 \mathrm{~m}$ a.s.l. The profile consisted of a sequence, about $1.75 \mathrm{~m}$ thick, of reddish brown laminated and banded carbonate rocks intercalated by red clays. The sequence was deposited over corroded or eroded surface of whitish massively recrystallised speleothems of unknown thickness.

\section{DESCRIPTION OF THE PROFILE}

The studied profile consisted of two parts: (1) older sequence of coarsely recrystallised speleothems, and (2) younger sequence of laminated to banded carbonate rocks with intercalations of red clays (Fig. 4; Photo 1). The fill was situated just below the levelled surface of the karst plateau and it consisted of several large blocks little displaced by blasting.

\section{Older sequence}

The older sequence consisted of a nearly white, very coarse-grained, recrystallised speleothem mass with distinct stalagmites completely surrounded by crystalline calcite (Fig. 4). This sequence 


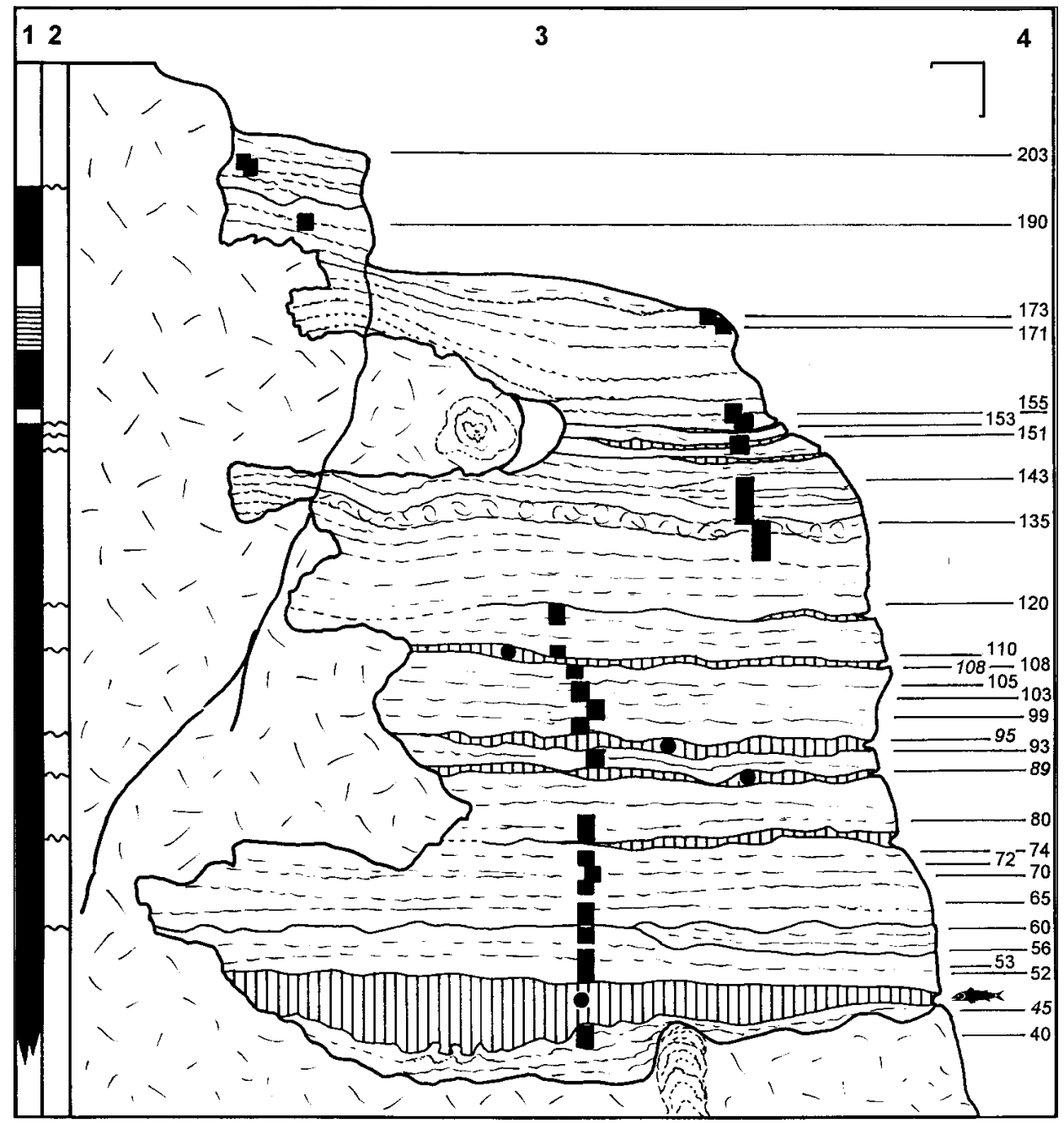

Fig. 4: Studied sequence in the Črnotiče Quarry.

1. Palaeomagnetic chart (black - normal polarized zone, white - reverse polarized zone, shaded unknown polarity), 2. Erosional surfaces, 3. Lithological log, 4. Numbers of samples, symbol finds of fossils.

clearly continued to speleothems covering rest of the walls of the host cave. The wall remains were nearly completely covered by sinter crusts with draperies and similar forms of speleothems.

The rocks of the older sequence were not sampled for palaeomagnetic analyses, because it is generally known that such very pure monomineral rocks lack carriers of remanent magnetisation (impurities of magnetic minerals). 


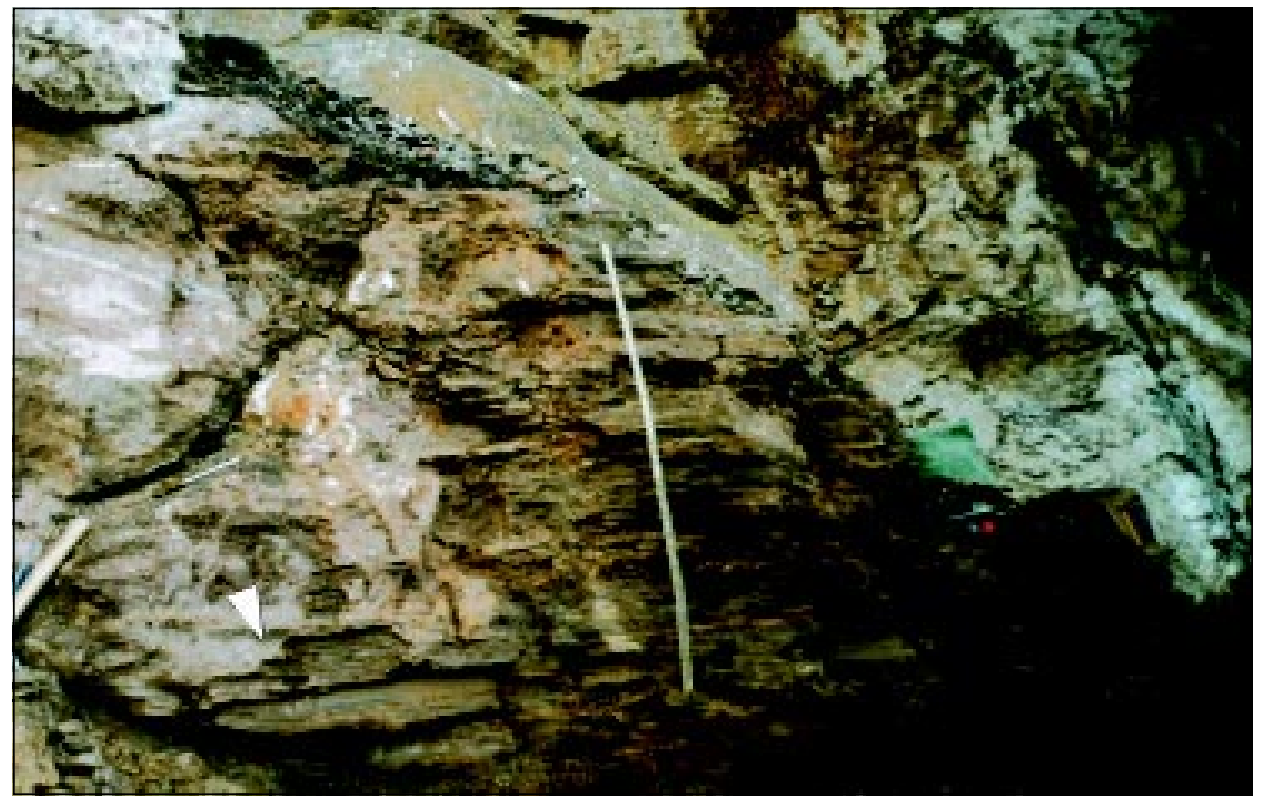

Photo 1: View of the profile in Črnotiče Quarry, arrow indicates the detail on Photo 2 (Photo by P. Bosák).

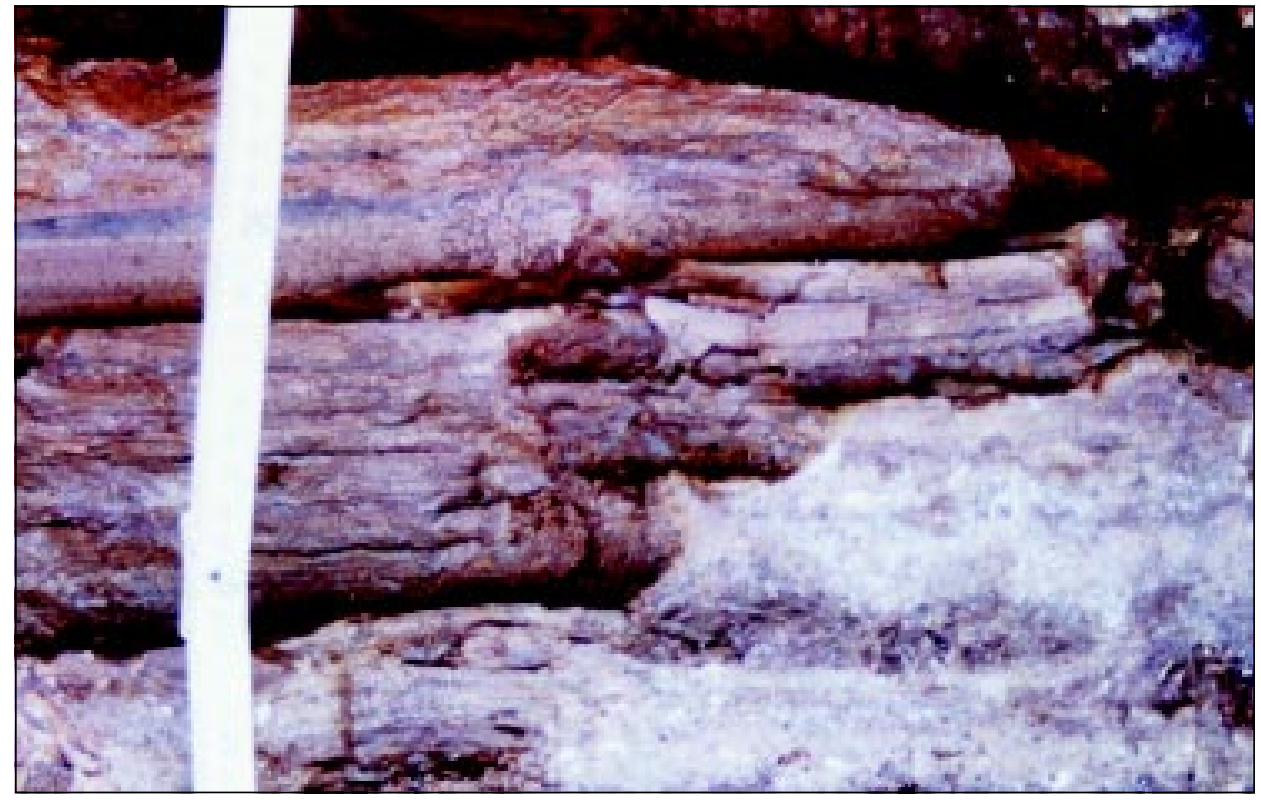

Photo 2: Corrosional contact of older sequence (coarse recrystallised speleothems) with carbonate rocks of the younger sequence (Photo by P. Bosák). 


\section{Younger sequence}

Carbonate rocks of the younger sequence filled a corrosional niche with a complex morphology carved in the older sequence (Photo 2). Rocks were laminated to banded with an alternation of bands of different texture, structure and colour. Individual bands were often separated by disconformities developed either as single erosional/corrosional surfaces or as intercalations of red clays. The total preserved thickness of this sequence was about $175 \mathrm{~cm}$.

Laminated/banded carbonate rocks of the younger sequence are composed of several types of rocks: (1) massive bands of internally laminated carbonate rock with beige and light grey colour. Thin laminae of brown colour can locally occur. In places, small vuggy porosity can be developed. In one place (layer No. 135, Fig. 4) the beige laminated flowstone is composed of ,columnar“ forms similar to ,stromatolites“ separated by thin films enriched in clay;

(2) bands of internally laminated carbonate rock of reddish brown, dark ochreous and light brown colour, with distinct content of impurities (clay, tiny concretions) and relatively abundant vuggy porosity;

(3) band of calcite-cemented cave sediments, i.e. highly calcitised clay, layers composed of tiny dark-coloured concretions.

Carbonates are often corroded. Larger pores are mostly elongated, parallel with lamination. Small pores are dominantly circular. Pores have uneven surface with clear selective corrosion of grains. Porosity walls are stained by ferrugineous materials. Some larger pores follow younger cemented cracks in rockss. Walls of some pores are covered by very fine lustrous carbonate crystals.

A total of 24 samples of carbonate rocks were sampled for analytical procedures. Samples had thickness from 2 to $9 \mathrm{~cm}$. They were numbered according to the height within the profile, i.e. number refers to centimetres from the base of documented profile.

Red clays form about 10 macroscopically distinct intercalations within the carbonate sequence with a thickness from several millimetres up to $16 \mathrm{~cm}$ (Fig. 4). Rock surfaces overlain by clays were often corroded in detail, sometimes into to uneven ridges (e.g. base of layer No. 45). Clays were red to brownish red, macroscopically homogeneous; sometimes disintegrable to small pieces. Some layers were composed of irregularly shaped clasts of more lithified red clays. In places, internal cementation of clays was developed in the form of irregularly shaped concretions. No coarse-grained admixture was macroscopically detected. Clays contained numerous tiny ovate dark-coloured concretions (pellets) with lustrous surface (warnish-like coatings). They often form an admixture also in banded carbonate rocks. No macroscopically distinct faunal remains were observed.

Four samples of clays were sampled for analytical procedures. They were numbered in a similar way to carbonates. Three samples were small, with a weight of several decagrams, as they were sampled from thin layers (No. 89, 95 and 108). The last sample (No. 45) from about $16 \mathrm{~cm}$ thick clay layer was sampled with a larger amount of about $2-3 \mathrm{~kg}$.

\section{MINERALOGICAL AND CHEMICAL ANALYSES}

Four clay samples were analysed in detail - No. 45, 89, 95 and 108. All samples were identified by X-ray diffraction and DTA-TG analyses. The larger amount of material from sample No. 45 enabled its washing. 


\section{Washing}

Large sample No. 45 was washed. The dry clay was at first decomposed using hydrogen peroxide and then washed through a $0.5 \mathrm{~mm}$ sieve. The rest with grain size over $0.5 \mathrm{~mm}$ was composed of dark-coloured pellet-ooid - like concretions [we will call them as pellets following view of Bushinsky (1971), as the expression is non-genetic and clear. The particles are adequate both to spheroids (,,roundgrains“) and to particles of concentric (orbiculate) structure of Bárdossy (1982, p. 130137)], fragments of calcite crystals and speleothems, irregularly-shaped cementation concretions and several faunal rests.

Pellets. Small concretions are of the size from 0.5 (given by the sieve) up to 2-3 mm. They are nearly ideally ovate, elongated, flat or irregular in shape, always with rounded edges. Their surface is dominantly lustrous, only in places dull. The colour is steel-grey to dark grey, only in places pale red to reddish brown. The internal structure in some specimens is concentric, ooid-like.

Calcite crystals and speleothem fragments. Small fragments of calcite crystals are present. They are pellucid to translucent and honey-coloured. Crystals are dominantly elongated, finely columnar. Translucent grains occur also as small scalenohedral and rhombic crystals, in places. Fragments of thin and highly corroded flowstone are present, too. Milky white homogeneous thin crusts, most probably thin speleothem coatings are also present.

Cementation concretions are light brown. They have a spongy appearance and contain numerous pellet-like concretions. They contain numerous small open cracks (septaria-like structure). Their size is up to fiew centimetres.

Fossil finds. A collection of micropalaeontological objects (18 specimens, 18 fragments) was found in the red clays. These objects may belong to the pharyngeal teeth of fishes, but its systematic position still remains unclear.

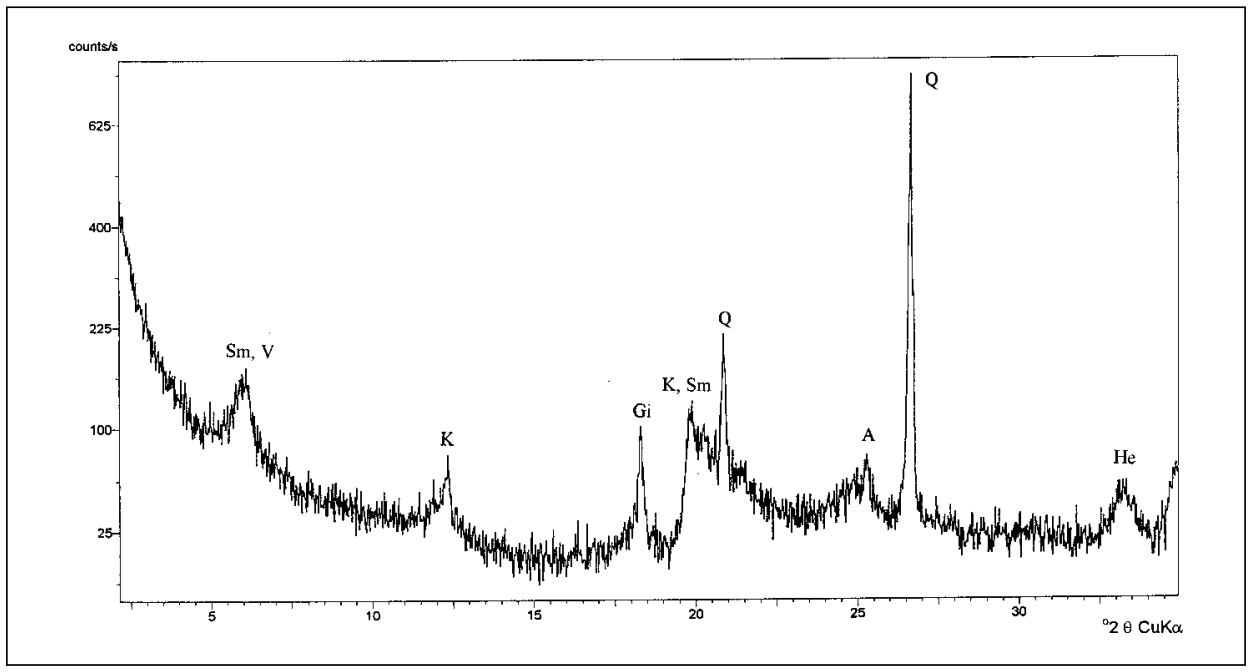

Fig. 5: A part of the X-ray diffraction pattern of the natural untreated sample of red clay No. C95B before separation, representing the mineral composition of red clay (for abbreviations see Table 3). 


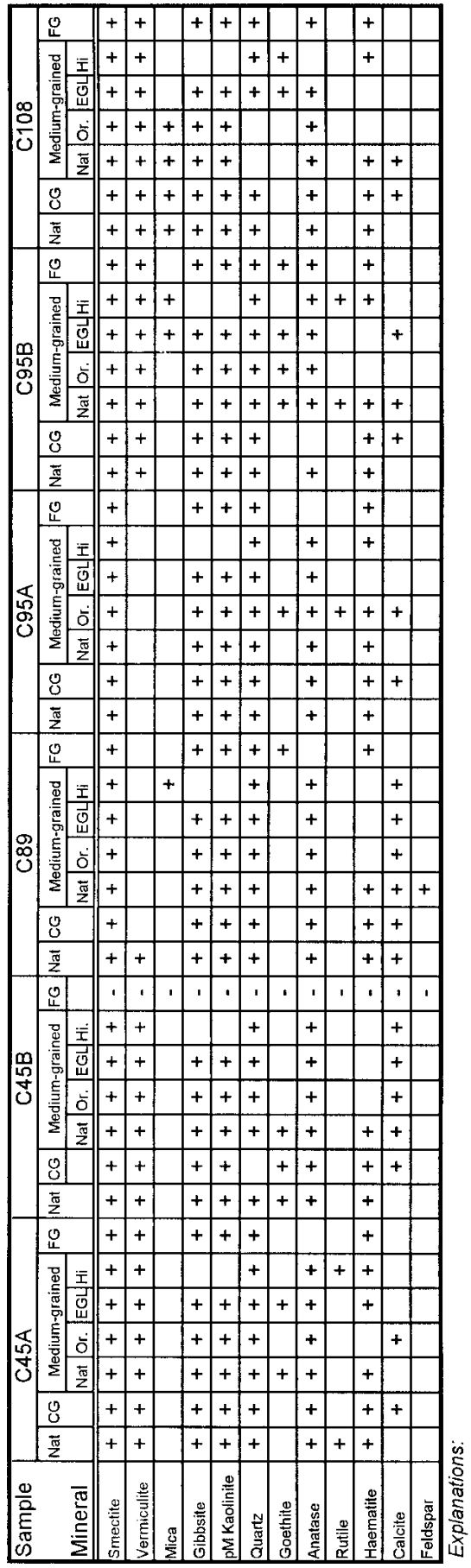

\section{X-ray diffraction analyses}

$\mathrm{X}$-ray diffraction analyses were performed using Philips X'Pert APD apparatus (goniometer equipped with graphite monochromator).

Samples of clays were divided by sieving into three grain-size fractions: coarse-grained (particles above $0.6 \mathrm{~mm}$ ), medium-grained (below $0.6 \mathrm{~mm}$, sedimented in water column) and fine-grained (remaining in suspension). The medium-grained fraction was studied: (i) in a natural state as the nonoriented sample using the commercial sample holder, (ii) as the oriented sample deposited on a glass slide, (iii) as the oriented sample saturated with ethylene glycol, and (iv) heated for 1 hour at $550^{\circ} \mathrm{C}$. Samples of pellets were studied in a natural state in the commercial sample holder and on glass.

Red clays. 6 samples of red clayey intercalations within the carbonate sequence were studied (C45A, C45B, C89, C95A, C95B and C108). The mineralogical composition is given in Table 1. Clays are composed of quartz, which is the dominating component in all samples. Smectite and vermiculite were proved by X-ray diffraction after saturation with ethylene glycol and after heating. DTA together with X-ray pattern identified undoubtedly the presence of $\mathrm{pM}$ kaolinite. The diffraction line at about $4.83 \AA$ A represents gibbsite and a line at about $3.52 \AA$ anatase in an accessory amount. Accessory rutile was also found. The diffraction between 9.9 and $10.1 \AA$ indicates very small amount of mica in some samples. Calcite occurred in a coarse-grained fraction in some cases. Haematite is a common constituent.

As an example for demonstration a part of the $\mathrm{X}$-ray diffraction diagram of the natural untreated sample (before separation) sample No. C95B is shown in Figure 5 together with its X-ray data of the whole pattern (Table 3).

Table 1: Mineralogical composition of red clays (resulting from X-ray diffraction and thermal analyses). 


\begin{tabular}{|c|c|c|c|}
\hline $\begin{array}{c}\text { d-spacing } \\
(\AA)\end{array}$ & $\begin{array}{c}\text { Relative intesity } \\
(\%)\end{array}$ & $\begin{array}{c}\text { Angle } \\
\left({ }^{\circ} \theta \mathrm{CuK} \alpha\right)\end{array}$ & Identified compounds \\
\hline 14.5 & 13 & 6.0 & Sm, V \\
\hline 7.18 & 7 & 12.3 & $\mathrm{~K}$ \\
\hline 4.84 & 14 & 18.2 & $\mathrm{Gi}$ \\
\hline 4.47 & 16 & 19.8 & $\mathrm{~K}, \mathrm{Sm}$ \\
\hline 4.25 & 31 & 20.8 & $\mathrm{Q}$ \\
\hline 3.59 & 3 & 24.7 & $\mathrm{~K}$ \\
\hline 3.52 & 7 & 25.7 & $\mathrm{~A}$ \\
\hline 3.34 & 100 & 26.6 & Q \\
\hline 2.696 & 5 & 33.2 & $\mathrm{He}$ \\
\hline 2.568 & 8 & 34.9 & $\mathrm{~K}$ \\
\hline 2.505 & 13 & 35.8 & $\mathrm{~K}, \mathrm{He}$ \\
\hline 2.457 & 10 & 36.5 & $\mathrm{Q}, \mathrm{Gi}$ \\
\hline 2.383 & 5 & 37.7 & $\mathrm{~K}, \mathrm{Gi}$ \\
\hline 2.324 & 8 & 38.3 & $\mathrm{~K}$ \\
\hline 2.282 & 7 & 39.4 & $Q$ \\
\hline 2.237 & 6 & 40.2 & Q \\
\hline 2.193 & 4 & 41.1 & K \\
\hline 2.128 & 5 & 42.4 & Q \\
\hline 1.982 & 3 & 45.7 & Q \\
\hline 1.876 & 6 & 48.4 & A \\
\hline 1.819 & 12 & 50.0 & $\mathrm{Q}$ \\
\hline 1.686 & 5 & 54.3 & $\mathrm{He}$ \\
\hline 1.542 & 14 & 59.9 & $\mathrm{Q}$ \\
\hline 1.490 & 6 & 62.2 & $\mathrm{~K}, \mathrm{He}$ \\
\hline 1.447 & 2 & 64.3 & $\mathrm{~K}, \mathrm{He}$ \\
\hline 1.382 & 3 & 67.7 & $\mathrm{Q}$ \\
\hline 1.375 & 7 & 68.1 & $\mathrm{Q}$ \\
\hline 1.372 & 5 & 68.3 & $\mathrm{Q}$ \\
\hline 1.287 & 21 & 73.4 & $\mathrm{Q}$ \\
\hline 1.284 & 10 & 73.6 & $\mathrm{~K}$ \\
\hline
\end{tabular}

Table 3: X-ray data of the natural untreated sample No. C95B before separation.

Explanations: Sm - smectite, $V$ - vermiculite, $K$ - kaolinite, $G i$ - gibbsite, $Q$ - quartz, $A$ - anatase, He-haematite

Pellets washed from the clays of sample No. C45 were composed of smectite, pM kaolinite, gibbsite, quartz, haematite, todorokite-like Mn hydroxyoxide, and anatase. The composition of the sample was nearly identical to the mineralogical composition of red clays, except the phase with high manganese content.

Note on the identification of smectites: smectite should reach the theoretical value of $16.9 \AA$ after saturation with ethylene glycol. In our samples, this value was a little lower, about $16.36 \AA$ on average, as a consequence of the interstratification. If we assume that the second partner for interstratification is vermiculite, our difractograms could indicate irregularly mixed layer structure of smectite-vermiculite with the predominance of smectite component. 
The saturation with ethylene glycol at $80{ }^{\circ} \mathrm{C}$ per 4 hours in a closed vessel causes the prolongation of the smectite unit cell. This procedure allows proof of the presence of smectite as well as vermiculite. During the saturation, smectite enlarges the length of its elementary cell, while in the case of vermiculite this does not happen and the X-ray diffraction is not shifted from its original $14 \AA$ value opposite to smectite. After heating to $550{ }^{\circ} \mathrm{C}$, the lattice of both minerals contracts to about $9.5 \AA$. This fact helps to exclude the presence of chlorite (its $14 \AA$ diffraction remains after heat treatment).

\section{Thermal analyses}

DTA-TG analyses were performed by "derivatograph" Q 1500 D (Orion, Hungary) with computerised registration of the own construction. DTA-TG analyses were carried out by a gradual heating $\left(10{ }^{\circ} \mathrm{C} \cdot \mathrm{min}^{-1}\right)$. A low temperature endothermic reaction at about $150{ }^{\circ} \mathrm{C}$ (Fig. 6) corresponds to the release of water from the lattice of smectite or vermiculite. An endothermic reaction at $300{ }^{\circ} \mathrm{C}$ represents the removal of hydroxyl water from the gibbsite lattice. Kaolinite is identified by the endothermic reaction at about $560{ }^{\circ} \mathrm{C}$ and by the exothermic reaction over $900{ }^{\circ} \mathrm{C}$ (recrystallisation of waterless phases).

Red clays. The character of thermal diagrams (Fig. 7) is nearly identical in all samples, confirming the presence of smectite, kaolinite and gibbsite, probably of some content of vermiculite, too. The weight loss varied between 13 and 16 percentages.

Pellets. The mineral composition is very similar to analyses of the red clays. The higher percentage of weight loss (20.9)

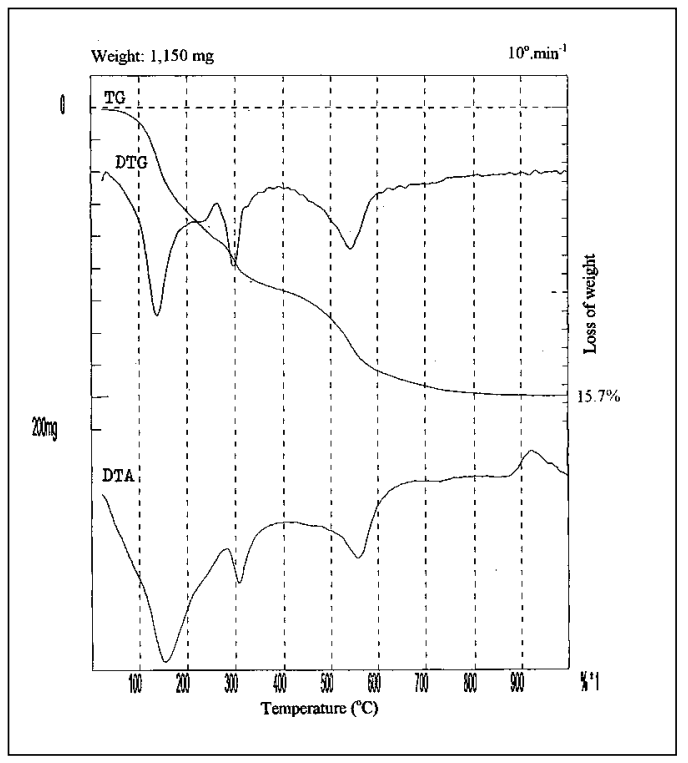

Fig. 6: TG, DTG and DTA curves representing the thermal behavior of red clay No. C95B (mediumgrained fraction).

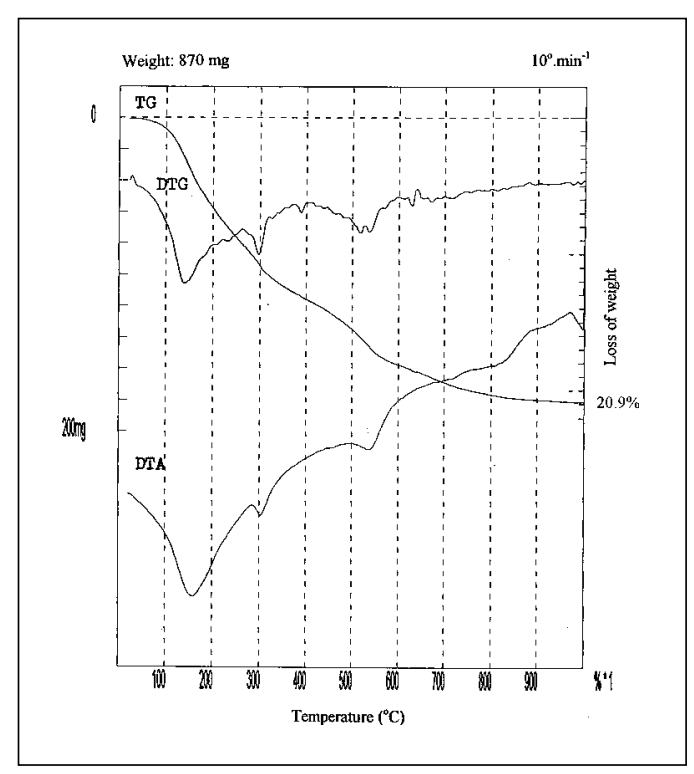

Fig. 7: TG, DTG and DTA curves of pellet. Note a higher loss of weight (20.9\%) than in red clays. 
on the TG curve (Fig. X3), as compared with red clays, indicates the presence of manganese hydroxyoxides, which corresponds to EDAX analysis and indications in the X-ray diffraction pattern.

\section{EDAX analysis}

Samples were studied by SEM and analysed places by EDAX (LINK connected to microprobe JEOL-JXA-50A).

Red clay. Sample $\mathrm{C} 89$ was analysed. High $\mathrm{Al}_{2} \mathrm{O}_{3}$ content reflects the presence of pM kaolinite and gibbsite, high Fe content can be connected with the presence of haematite, possibly goethite, too (cf. Table 1).

Pellets. Two samples of pellets washed from sample $\mathrm{C} 45$ were studied, in a natural state and as broken pieces. It is worth of mentioning that pellets were transmissive; it was not necessary to plate the surface for analyses by metal. Washed pellets from sample No. C45 were analysed in polished thin section. Another pellet was studied in a rock plate, remaining after the thin section preparation (sample C108).

Analytical results are summarised in Table 2. The content of $\mathrm{MnO}$ is surprisingly high, from about 4 to more than $68 \mathrm{wt} . \%$ (common content is from about 22 to $44 \mathrm{wt} . \%$ ). Correspondingly also $\mathrm{FeO}$ and $\mathrm{Fe}_{2} \mathrm{O}_{3}$ contents are high, from about 2.4 to 22.89 wt.\%, but they are generally lower than in red clays. Slightly increased $\mathrm{TiO}_{2}$ content (0.12-3.41 wt.\%) reflects identified anatase and rutile. One grain with 99.57 wt.\% of $\mathrm{TiO}_{2}$ represented rutile. High $\mathrm{Al}_{2} \mathrm{O}_{3}$ contents (5.57-29.26 wt.\%) correspond to proved contents of gibbsite and pM kaolinite. The distribution of $\mathrm{MnO}$ and $\mathrm{FeO}+$ $\mathrm{Fe}_{2} \mathrm{O}_{3}$ within samples is very irregular, in places, probably reflecting the concentric ooid-like structure of pellet.

Sample C108 (analyses No. 3/1-3/8) is characterised by concentric structure with increasing trend in $\mathrm{Fe}, \mathrm{Al}$ and $\mathrm{Si}$ contents from the outer zone to the centre and with decreased manganese in the same direction. It seems that central parts of the pellet are built by clay minerals enriched in ferrugineous substances and the outer zone is rather composed of manganese compounds.

In the sample of washed pellet (sample No. C45) the trend is opposite to sample No. C108 (analyses No. 6/1-6/8). The nucleus is built of Mn-rich minerals ( $c f$. analyses No. 7/1-7/4), while outer zones contain more kaolinite and especially Al-rich minerals ( $c f$. analyses No. 5/2-5/13). Also this pellet shows a concentric structure with laminae enriched either in Mn-rich minerals (e.g. analysis No. 5/10) or in Al-rich minerals (e.g. analyses No. 5/9 and 5/11). Clastic quartz grains and rutile (analysis No. 5/1) are present.

High chromium content is remarkable in numerous analyses. Samples contained a high percentage of water, which corresponds to the presence of $\mathrm{Mn}$ and Fe hydroxyoxides. Also some organic carbon was present.

One pellet was composed of xenotopic mosaic of pure calcite (analysis No. 4/1) encircling nucleus enriched in Mn-rich minerals, kaolinite and Al-rich minerals (analyses No. 4/2-4/6). Intergranular space between calcite grains is filled with kaolinite (analysis No. 4/8). Clastic quartz grains are present, too (analysis No. 4/7).

\section{Discussion}

Results of mineralogical analyses indicate a relatively uniform mineralogical composition both of red clays and pellets. Quartz, smectite, vermiculite, pM kaolinite, gibbsite, and anatase represent 


\begin{tabular}{|c|c|c|c|c|c|c|c|c|c|c|c|c|c|}
\hline $\mathrm{pu}$ & 196 & pu & $86 \mathrm{te}$ & $\varepsilon z 0$ & $I S 1$ & $\mathrm{pu}$ & I90 & $\varepsilon z^{\prime} z$ & $89^{\circ}$ & $8 z^{\prime}(0)$ & $\varepsilon \varepsilon 8$ & $9 L S$ & $t / L$ \\
\hline $\mathrm{pu}$ & $8 t^{\circ} L$ & pu & $\pi L \cdot z z$ & 0 & $t z^{\prime \prime} 1$ & $\mathrm{pu}$ & 560 & $\angle L^{\prime} \mathrm{I}$ & $2 \mathrm{I} 0$ & IS 0 & 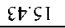 & $6 L t b I$ & $\varepsilon / L$ \\
\hline $\mathrm{pu}$ & $91 \%$ & pu & $\varepsilon t \varepsilon$ & $1 b^{\circ} 0$ & 251 & $\mathrm{pur}$ & 590 & $6 I^{\prime} \mathrm{Z}$ & $E \varepsilon 0$ & $\tau \varepsilon^{\prime}(0)$ & $S \varsigma L$ & $660^{2}$ & $Z / L$ \\
\hline$p u$ & $s z t$ & pit & $\overline{Q L E}$ & $s z 0$ & $5 \varepsilon 7$ & $\mathrm{pu}$ & $t E 0$ & $z \varepsilon \tau$ & $02^{\prime} 0$ & $\angle \varepsilon 0$ & $t 59$ & 98 & $I / L$ \\
\hline & zLII & Dit & 181 & 000 & 511 & pii & 160 & 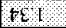 & 820 & 60 & 161 & 14 & 819 \\
\hline $\mathrm{pu}$ & 888 & Dij & IECCl & 180 & 980 & $\mathrm{pit}$ & 160 & $10 \% 4$ & 850 & 980 & 8881 & 0281 & 49 \\
\hline $\mathrm{pr}$ & 1718 & $\mathrm{pr}$ & tolz & 600 & de. & pii & 89.0 & $18 \%$ & & 160 & $10 \%$ & $\%+1$ & $9 / 9$ \\
\hline $\mathrm{pit}$ & 161001 & 10 & $6 / 02$ & ETO & 611 & $\mathrm{pri}$ & 160 & 281 & 10100 & 100 & 8881 & 28.41 & 99 \\
\hline $\mathrm{pH}$ & 1028 & Du & 2962 & 6 & $1 \%$ & $\mathrm{pit}$ & 160 & 361 & 960 & 870 & 806 & 14 & 79 \\
\hline pro & $12 \%$ & pu & $1 / 187$ & 110 & 801 & $\mathrm{MI}$ & 060 & $\sqrt{0.1}$ & 480 & 210 & 1786 & 128 & 89 \\
\hline pi & 1628 & PG & 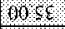 & 0 & \&S 1 & $\mathrm{PI}$ & 800 & 1712 & 110 & 120 & 899 & $96 \%$ & 69 \\
\hline pir & $11 \%$ & pus & $101 \%$ & 1620 & 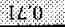 & $\mathrm{pu}$ & 660 & oro & 1100 & 810 & 8871 & 602 & 119 \\
\hline Pu & t6. II & $\mathrm{pu}$ & $08^{\circ} 91$ & szo & $8 L^{\circ} 0$ & $\mathrm{pu}$ & OIII & {$\left[b^{\circ} 1\right.$} & II $Z^{\prime} 0$ & $\varepsilon \varsigma_{0}$ & $8 \tau \cdot \tau \tau$ & $\varepsilon 9^{\circ} \mathrm{IZ}$ & $\mathrm{EI/S}$ \\
\hline $\mathrm{pu}$ & 229 & $\mathrm{pu}$ & $19.5 \mathrm{I}$ & sio & 690 & $\mathrm{pu}$ & 18.1 & $06 . \mathrm{I}$ & $9 \mathrm{I}^{\circ} 0$ & $80^{\circ} 0$ & $\angle t \varepsilon Z$ & $I z+t z$ & $\mathrm{ZI/S}$ \\
\hline $\mathrm{pu}$ & $59 \mathrm{~L}$ & $\mathrm{pu}$ & $28^{\circ} \mathrm{L \tau}$ & Elo & $E<0$ & $\mathrm{pu}$ & 28.0 & $66^{\circ} \mathrm{I}$ & $19 \%$ & $S I^{\prime} 0$ & $09 \varepsilon \mathrm{I}$ & $t S^{\prime} L$ & $I \mathrm{I} / \mathrm{S}$ \\
\hline pi & $O L \varepsilon$ & $\mathrm{pu}$ & $99^{\circ} 0 \varepsilon$ & 720 & 580 & $\mathrm{pu}$ & $66^{\circ} 0$ & $0 L I$ & $65^{\circ} 0$ & II'0 & $\varepsilon 56$ & $65^{9} 9$ & $0[/ \mathrm{S}$ \\
\hline pu & 596 & $\mathrm{pu}$ & $\varepsilon 0+\tau$ & 200 & EOT & $\mathrm{pu}$ & $00^{\circ} 1$ & $79^{\circ} \mathrm{I}$ & $t 50$ & 850 & $88 \angle 1$ & $59 \varsigma \mathrm{I}$ & $6 / \mathcal{S}$ \\
\hline pu & LLt & pu & $290 \varepsilon$ & 0 & 690 & $p u$ & $9 \mathcal{L}^{\circ} 0$ & I8. I & $60^{\circ} 0$ & $6 Z^{\prime} 0$ & t5lol & 109 & $8 / \mathrm{S}$ \\
\hline pu & 658 & $\mathrm{pu}$ & 89.12 & 0 & 660 & pu & $\angle I^{\circ} T$ & $96^{\circ} \mathrm{I}$ & 580 & $\varepsilon+0$ & 26,1 & $t E 91$ & $L / S$ \\
\hline $\mathrm{pu}$ & 298 & pu & $8 \varepsilon^{\circ} \mathrm{IZ}$ & 210 & 111 & PI & $E 0^{\circ} \mathrm{I}$ & $0 \angle \mathrm{I}$ & $9 \tau 0$ & $\operatorname{ss} 0$ & $\angle L 9[$ & 0151 & $9 / 5$ \\
\hline pu & 569 & pu & $\varepsilon<+\tau$ & $\angle Z^{\circ} 0$ & $0 S^{\circ} 1$ & $\mathrm{pu}$ & $2 t .1$ & $08 \mathrm{I}$ & $\angle E 0$ & $99^{\circ} 0$ & $\angle E 81$ & 5981 & $S / S$ \\
\hline $\mathrm{pu}$ & 8601 & $\mathrm{pu}$ & tI.92 & 210 & $2 Z^{\prime}$ & $\mathrm{pu}$ & 0660 & IL'I & $2 \neq 0$ & 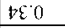 & $6+21$ & 8011 & $t / \mathcal{S}$ \\
\hline $\mathrm{pu}$ & 569 & $\mathrm{pu}$ & $98 \mathrm{LZ}$ & SI'0 & $\angle 60$ & pu & 090 & $\angle L I$ & 580 & $\nabla z^{\prime} 0$ & IL6 & $t+9$ & $\mathcal{E} / \mathcal{S}$ \\
\hline $\mathrm{pu}$ & 969 & pu & $89^{\circ} \mathrm{LI}$ & 0 & $88^{\circ}$ & pu & $\varepsilon 0 \mathrm{I}$ & LSI I & OZ 0 & $0 \angle 0$ & 1691 & $\angle 8 \angle 1$ & $Z / S$ \\
\hline $\mathrm{pu}$ & $15^{\circ} 0$ & $\mathrm{pI}$ & $\angle 80$ & 200 & $\angle S C$ & pII & 0 & 0 Г० 0 & 0 & $\varepsilon I 0$ & 010 & 250 & $\mathrm{I} / \mathrm{S}$ \\
\hline pu & 880 & $\mathrm{PI}$ & 1820 & 020 & $2<0$ & 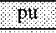 & 660. & 401 & $\angle 80$ & 921 & $1+41$ & 8008 & $8 / t$ \\
\hline $\mathrm{BI}$ & 420 & 14. & 180 & 010 & 210 & 10 & 920 & 200 & 0 & 0 & 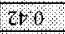 & 666 & 40 \\
\hline pro & 814 & $\mathrm{DU}$ & ES s & 20 & 950 & bI & 601 & $16 \%$ & 260 & 60 & $02<1$ & 811 & $9 / 4$ \\
\hline pir & 17501 & $\mathrm{pil}$ & bst & Z2) & 260 & $1 \mathrm{pH}$ & 601 & 161 & $18 \% 0$ & SSO & 0016 & tLL? & ett \\
\hline pir & 819 & $\mathrm{Pu}$ & 12121 & 120 & 920 & Di: & 601 & 501 & 120 & 1800 & otsil & 5601 & 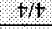 \\
\hline pit & 190 & pit & 8646 & 220 & 650 & $10 \%$ & 1602 & 102 & 0 & 1080 & $6 \%<2$ & $28: 16$ & $81 t$ \\
\hline $\mathrm{pH}$ & 1918 & pit & $t+6$ & 720 & 660 & $\mathrm{DH}$ & $10 \% 1$ & 1072 & 810 & 60,0 & $216 \%$ & 9181 & at \\
\hline $\mathrm{pur}$ & 170 & pir & 1500 & 1210 & 910 & 11 & 020 & $84 \%$ & 0 & 1020 & 910 & $2 z 0$ & $1 / 1$ \\
\hline$\angle E O$ & $0 \mathrm{I}^{\circ} 9 \mathrm{I}$ & PI & $t 091$ & $2 \varepsilon 0$ & $t s$ & $\mathrm{pu}$ & 601 & $\angle \varepsilon \varepsilon$ & $t 10$ & 860 & $10 \angle 2$ & $\varepsilon 0 \varepsilon \varepsilon$ & $8 / \mathrm{\varepsilon}$ \\
\hline$I+0$ & ESIZ & $\mathrm{pu}$ & $50^{\circ} 9 \mathrm{I}$ & $85^{\circ} 0$ & $1 t^{\prime}$ & $\mathrm{pur}$ & $6 \angle 0$ & {$[\angle \mathcal{E}$} & 0 & $98^{\prime} 0$ & $t \varepsilon+2$ & $Z L 8 Z$ & $L / \mathcal{E}$ \\
\hline 0 & $E I ' z I$ & $\mathrm{pu}$ & $\tau z 0 t$ & $0 z^{\prime} 0$ & $0 \tau^{\circ}$ & $\mathrm{pu}$ & $\varepsilon \angle 0$ & $\angle t^{\prime} \theta$ & $z / 0$ & $S L 0$ & 0561 & $698 \mathrm{I}$ & $9 / \zeta$ \\
\hline 900 & $\tau \varepsilon \varepsilon \mathrm{I}$ & $\mathrm{pu}$ & tI: $Z \varepsilon$ & $t\left[0^{\circ} 0\right.$ & $\angle L^{\circ}$ & PII & $t 80$ & $68 t$ & $\angle 00$ & 902 & $\angle 9 I Z$ & $z \tau \varepsilon \tau$ & $\varsigma / \mathcal{S}$ \\
\hline 620 & $\angle 9 S I$ & $\mathrm{pu}$ & $\angle E O E$ & $\varepsilon \varepsilon 0$ & $15^{\circ}$ & $\mathrm{pu}$ & $6 \angle 0$ & $8 L S$ & $\angle 10$ & $2 L 0$ & $\varepsilon+0 z$ & $96 \varepsilon z$ & $t / \mathrm{c}$ \\
\hline$\varsigma \neq 0$ & $68^{\prime} z 2$ & $\mathrm{PII}$ & $\varepsilon 80 t$ & 680 & $\angle 9$ & $\mathrm{pu}$ & 180 & $\varepsilon S 8$ & $t z^{\prime} 0$ & 190 & $E t[I$ & IIZI & $\varepsilon / \mathcal{E}$ \\
\hline $2+0$ & $\angle 0 \varepsilon I$ & $\mathrm{pu}$ & $85^{\circ} 9 \mathcal{E}$ & $t 2 \cdot 0$ & $09^{\circ}$ & $\mathrm{pu}$ & 960 & $Z L S$ & $t z \cdot 0$ & $t \varepsilon 0$ & $6 \leqslant 61$ & $t+0 z$ & $z / \varepsilon$ \\
\hline$z \tau 0$ & $9 t \leq s$ & $\mathrm{pu}$ & $\varepsilon 089$ & $5 \rho_{0}$ & 62 & pu & $\operatorname{se} 0$ & $\angle t O I$ & SI0 & 900 & $\angle S S$ & 589 & $I / \mathcal{E}$ \\
\hline$p^{* t}$ & 18681 & jil & $87+8$ & WII & 662 & 8180 & 660 & $180 \%$ & 910 & 1:201 & $29 \mathrm{ll}$ & 6061 & $8 / 2$ \\
\hline pu & $10+5$ & $\mathrm{put}$ & 8665 & Vov & 870 & 892 & 110 & $\angle S$ & 200 & 180 & 901 & 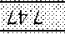 & 42 \\
\hline 10 & $2+11$ & pit & $05 \%$ & 101 & 220 & 681 & 920 0 & 86 & 0 & 800 & $\mathrm{sq} 2 \mathrm{c}$ & $102 \mathrm{z}$ & $9 / 2$ \\
\hline 114 & 226 & 18 & 809 & pro & 150 & 680 & 10! & 131 & S10 & 180 & 8901 & 9160 & 50 \\
\hline $\mathrm{pt}$ & 8001 & pil & $1 / 12$ & bet & Sso & 890 & 200 & 152 & 0 & 150 & 9262 & lothe & Th2 \\
\hline pu & 1796 & pei & $6 t+1$ & Du & 111 & 6.1 & 020 & Lef & 0 & $18 \%$ & 2. 13 & 1004 & $\varepsilon / 2$ \\
\hline Pr: & gr z & pH & $69 \mathrm{~K}$ & pir & $2+0$ & $601 \%$ & 860 & 1508 & 0 & 820 & $1 \%$ \& & 6012 & $2 / 2$ \\
\hline 19 & 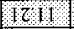 & pil & $1206 \mathrm{~s}$ & m & 150 & $51 \%$ & se 0 & 1421 & 400 & 440 & 9161 & 412 & $1 / 2$ \\
\hline $\mathrm{pu}$ & pu & $I Z \subseteq \mathrm{I}$ & $\varepsilon \varepsilon \sigma \varepsilon$ & $\mathrm{pu}$ & $0 E^{\prime}$ & $\mathrm{pu}$ & 660 & $0 S^{\prime} \mathcal{E}$ & pu & Ell & $t \varepsilon \varepsilon \varepsilon$ & $0 z+\tau$ & $9 / 1$ \\
\hline pu & $\mathrm{pu}$ & $\varsigma_{66 \mathrm{ZI}}$ & $6 \angle D E$ & $\mathrm{ptr}$ & $\varepsilon 0^{\circ}$ & pu & $8 L 0$ & $I S \varepsilon$ & $\mathrm{pu}$ & 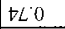 & $0 t^{\prime} t z$ & 0812 & $\varsigma /[$ \\
\hline $\mathrm{pu}$ & $\mathrm{pu}$ & $99 \mathrm{ZI}$ & $6 \varepsilon \mathcal{E \varepsilon}$ & pu & $9 l^{\prime T}$ & pI & 950 & $66 \hat{\varepsilon}$ & pu & $0+1$ & $\varepsilon 62 z$ & $\tau t+\tau$ & $t / \mathrm{I}$ \\
\hline $\mathrm{pu}$ & $\mathrm{pu}$ & $29+1$ & $O L C Z$ & pu & $I \angle \circ 0$ & pur & $0 I^{\prime} \mathrm{I}$ & $I 6^{\prime} \varepsilon$ & pur & 581 & $9+2 z$ & $\forall I^{\prime \prime Z \varepsilon}$ & $\varepsilon / /$ \\
\hline $\mathrm{pll}$ & $\mathrm{pu}$ & $\angle I^{\prime} Z I$ & $S L \angle Z$ & $\mathrm{pur}$ & $I Z^{\prime} I$ & $\mathrm{pu}$ & $S I^{\prime} I$ & $80^{\circ} \mathrm{t}$ & PII & EIT & $0 \varepsilon z 2$ & $500 \varepsilon$ & $z / \mathrm{I}$ \\
\hline pu & $\mathrm{pu}$ & 586 & $80^{\circ} 0 \mathrm{~s}$ & $\mathrm{pu}$ & 860 & $\overline{\mathrm{pu}}$ & $\varepsilon z^{\prime} 9$ & $\angle \sigma^{\circ} \mathrm{S}$ & PII & 260 & $\varsigma \varepsilon \varepsilon I$ & 20.81 & $\mathrm{I} / \mathrm{I}$ \\
\hline 1\% & 2812 & pis: & 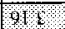 & 100 & 012 & 164 & 801 & 812 & 800 & 169 & 18l2 & 6668 & Re \\
\hline os & ${ }^{\varepsilon} O^{\tau_{3}} \cdot \mathbf{A}$ & $\mathrm{O}_{\mathrm{H}}$ & OUN & ${ }^{{ }^{2}} \mathbf{O}^{x_{x}, j}$ & ${ }^{z_{0} \text { O!. }}$ & ovg & $\boldsymbol{o s}_{\mathbf{I}} \mathbf{N}$ & $\mathrm{O}_{0}, 3$ & $O^{2 v_{N}}$ & $O^{z} \mathbf{Y}$ & ${ }^{8} O^{z} \mathbb{Y}$ & ${ }^{2} \mathrm{O}$ OS & \\
\hline
\end{tabular}

Table 2: Chemical EDAX analyses.

Note: $n d$ - not determined; clay-sample No. C89; 1/1 to 1/6-whole pellet, washed from sample No. C45; 2/1 to 2/8 broken pellet, washed from sample No. C45; 3/1 to 3/8 pellet inside speleothem, sample No. C108; 4/1 to 4/8-carbonate pellet, washed from sample No. C45, polished thin section; 5/1 to 7/4-pellet, washed from sample No. C45, polished thin section 
the principal constituents. The composition is very similar to analyses of terra rossa type of soils from the territory of past Yugoslavia ( $c f$. Bárdossy 1982, p. 329-338). Pellets contain distinctly higher proportion of manganese-rich minerals (todorokite), in places. In our samples, we found relatively abundant vermiculite, which is unknown from bauxites (Bárdossy 1982, p. 336), on the other hand, the content of gibbsite is remarkable.

The chemical composition of pellets shows several important data. There is increased content of chromium in numerous analyses $\left(0.10-0.41 \%\right.$ of $\mathrm{Cr}_{2} \mathrm{O}_{3}$, i.e. roughly 100 to $250 \mathrm{ppm}$ of $\mathrm{Cr}$ ). In literature it is mentioned that increased chromium content is typical for the hypergenic zone - laterites and especially bauxites - where chromium is associated with aluminium as hydroxides of both metals precipitate at close $\mathrm{pH}$ values. The increased $\mathrm{Cr}$ content can be linked with an important content of chromite found in the heavy mineral fraction of cave sediments in the Dimnice Cave (up to $8 \%$ ). Cave sediments were derived from Eocene flysh of the Brkini Mts., which contains up to 1 $\%$ of chromite (Zupan Hajna 1998, pp. 174-175). The zone of the Brkini Mts. is situated in the same tectonic zone close to the studied site.

The chemical ratios of $K_{i}$ (Harrassowitz 1926, i.e. $\mathrm{SiO}_{2}$ wt. $\% / \mathrm{Al}_{2} \mathrm{O}_{3}$ wt. $\%$ x 1.7) obtained for pellets do not correspond to ratios typical for bauxites. The $K_{i}$ values correspond to those typical for terra rossa ranging from 0.9 to 2.43. The major part of the values spans from 1.45 to 2.01. According to de Weisse (1948) $K_{i}$ values from 0.5 to 2 are characteristic for terra rossa, although they can be sometimes higher or lower.

According to the above-mentioned data, red clays represent most probably redeposited weathering products of a terra rossa type. Nevertheless, the presence of abundant Fe-Mn pellets, and some mineralogical and geochemical data indicate that red clays intercalated within the speleothem sequence could represent redeposited older paludal deposits, with the depositional history close to Tertiary deposits in Rheinische Schiefergebirge (FRG) with high mobility of manganese ( $c f$. Berger 1968). Such sediments deposited from eroded weathering profiles both on limestones and flysch (heavy minerals, feldspars) in water-saturated environment of lakes to marshes. Paludal sediments underwent an initial phase of bauxitisation, as indicated by increased chromium content, indications of aluminium replacement of some of Mn-rich pellets and abundant gibbsite.

\section{THIN SECTION ANALYSIS}

Thin sections were prepared from all samples for the palaeomagnetic analysis, i.e. totally 27 thin section of carbonate rocks. Classical covered thin section (max. 2 by $3 \mathrm{~cm}$ in size) were produced. One covered thin section was prepared from washing residuum obtained from sample No. C45, to study pellets.

\section{Carbonate rocks}

Microscopic review of carbonates detected very special textural composition. They are dominantly composed of xenotopic to hypidiotopic mosaic of carbonate grains with the size starting at $0.01 \mathrm{~mm}$, which is unusual in classical speleothems of the flowstone type. Some laminae to bands are more coarse-grained, or recrystallised. Typical columnar texture characteristic for flowstones appears only in rare bands. The general structure of all samples studied is finely laminated to thinly banded. There is the alternation of laminae and bands, enriched in clastic material with 
laminae and bands more or less without clastic admixture. Lamination to banding is often gradational, fining upward. Nevertheless, internal erosional surfaces are very rare. If such a surface is developed, it is stained by iron compounds. Sample No. C135 has a different texture. It is composed of curved columnar forms built of lamination common as in other samples.

Clastic material has dominantly size from coarse-grained silt to very fine-grained sand. It is well to medium sorted, if the grain-size is generally coarser, clastic admixture is poorly sorted with indistinct to clearly developed bimodal grain-size distribution. Clastic admixture is composed of predominant detrital quartz grains, very often ferrugineous pellets, relatively abundant mica plates, accessory feldspars (fresh and sericitised), tourmaline, rutile, zircone, and (?) apatite.

Quartz grains are mostly angular to subangular, sometimes even rounded (larger grains). They are often elongated or they have the form of angular shards. From time to time they are corrosionally overlain by a ferruginous substance. Composed quartz grains are accessory (fragments of finegrained quartzites).

Pellets have different sizes, from coarse-grained silt up to coarse-grained sand, or very finegrained gravel. They are connected with increased content of clastic admixture or they enrich bands with very low clastic content.

Carbonates contain small fragments of recrystallised older speleothems and rare objects, which can be identified as remains of fossils. In one case, shell similar to that washed from red clays was observed. In some cases, there probably exist fossil remains, which cannot be identified, maybe of mammal bones.

Carbonate sediments resemble common limestones, rather than classical flowstones. Columnar texture highly resembles algal constructed forms (stromatolitic-like texture) also other characteristics of lamination could indicate its origin from organic-rich films (algal or diatom mats) on which fine carbonate grains were trapped or crystallised. Similar sediments were described e.g. by Bosák et al. (1984) from Na Turoldu Cave, Southern Moravia, Czech Republic.

\section{Pellets}

Pellets are predominantly ovate, sometimes they are irregular in shape. They are composed of an homogeneous opaque mass enclosing relatively not abundant angular quartz grains, grains of carbonate (calcite). In some cases pellets show translucent rims close to the outer contour, filled by kaolinite. Kaolinite fills also fine cracks resembling contraction cracks originated by dessication.

\section{PALAEOMAGNETIC MEASUREMENTS}

Totally 27 oriented laboratory samples have been investigated for their palaeomagnetic properties.

\section{Laboratory procedures}

Laboratory procedures were combined in a way enabling the derivation of respective components of magnetic remanence within different temperature intervals during progressive thermal demagnetization (TD), and the determination of moduli and directions of remanent magnetization. The value of magnetic susceptibility, as well as the determination of minerals, carriers of respective components of remanence components, and phase or mineral changes. 
Oriented hand samples were collected in the field from individual carbonate layers. Laboratory samples, i.e. small cubes 20 by 20 by $20 \mathrm{~mm}$ were cut from field samples. Cubes were later measured on the spinner magnetometers JR-4 and JR-5 (Jelínek 1966).

All laboratory samples in natural state were subjected to progressive thermal demagnetization in 10 to 12 thermal fields using the MAVACS (Magnetic Vacuum Control System). The apparatus generates high magnetic vacuum in medium thermally demagnetized samples (Př́hoda et al. 1989). The remanent magnetization of samples in natural state (NRM) is identified by the symbol $J_{\mathrm{n}}$, the corresponding remanent magnetic moment by the symbol M. Graphs of normalized values of $M / M_{0}$ $=\mathrm{F}(\mathrm{t})$ were constructed for each analyzed sample.

The directions of $J_{\mathrm{n}}$ and of the remanent magnetization of thermally demagnetized samples in the course of the progressive demagnetization procedures are shown in stereographic projection in Fig. 9. The full (blank) small square designates projection onto the lower (upper) hemisphere.

The orthogonal projection of the remanent magnetization vectors is shown by the Zijderveld's diagrams, where a full small square indicates projection onto a horizontal plane (XY) and a blank small square indicates projection onto a north-south vertical plane (XZ). The natural state of specimens is designated by the NS value.

Phase or mineralogical changes of magnetically active (mostly Fe-oxides) minerals frequently occur during laboratory thermal tests, especially at low temperature intervals. These changes can be derived from the graphs of normalized values of $k_{\mathrm{t}} / k_{\mathrm{n}}=\mathrm{f}(\mathrm{t})$, where $k_{\mathrm{n}}$ designates the volume magnetic susceptibility of

\begin{tabular}{|l|c|c|c|}
\hline No. of sample & $\begin{array}{c}\text { Thickness } \\
(\mathrm{m})\end{array}$ & $\begin{array}{c}J_{\mathrm{n}} \\
(\mathrm{nT})\end{array}$ & $\begin{array}{c}k_{\mathrm{n}} \\
\left(10^{-6} \mathrm{SI}\right)\end{array}$ \\
\hline C40 & 0.40 & 56.124 & 566 \\
\hline C52 & 0.52 & 99.249 & 1524 \\
\hline C53 & 0.53 & 127.578 & 1785 \\
\hline C56 & 0.56 & 40.163 & 905 \\
\hline C60 & 0.60 & 37.014 & 768 \\
\hline C65/1 & 0.65 & 48.513 & 403 \\
\hline C70 & 0.70 & 74.326 & 941 \\
\hline C72 & 0.72 & 52.152 & 1344 \\
\hline C74 & 0.74 & 149.408 & 3171 \\
\hline C80 & 0.80 & 103.243 & 2152 \\
\hline C93 & 0.93 & 153.364 & 2513 \\
\hline C99 & 0.99 & 262.068 & 4738 \\
\hline C103 & 1.03 & 224.544 & 3846 \\
\hline C105 & 1.05 & 213.762 & 3767 \\
\hline C108 & 1.08 & 212.632 & 3631 \\
\hline C110 & 1.10 & 207.984 & 3544 \\
\hline C120 & 1.20 & 54.787 & 1004 \\
\hline C135B & 1.35 & 72.003 & 1270 \\
\hline C143A & 1.43 & 53.989 & 740 \\
\hline C150A & 1.50 & 46.177 & 798 \\
\hline C151 & 1.51 & 68.852 & 1169 \\
\hline C153 & 1.53 & 51.875 & 1166 \\
\hline C155 & 1.55 & 189.432 & 1785 \\
\hline C171 & 1.71 & 57.432 & 1077 \\
\hline C173 & 1.73 & 61.533 & 1272 \\
\hline C190 & 1.90 & 59.614 & 1143 \\
\hline C203 & 2.03 & 51.506 & 989 \\
\hline Number of samples & 27 & 27 \\
\hline mean value & & 104.790 & 1778 \\
\hline Standard deviation & & 69.609 & 1204 \\
\hline & & & \\
\hline
\end{tabular}

Table 4: Natural remanent magnetization $\left(J_{n}\right)$ and volume magnetic susceptibility $\left(k_{n}\right)$ of samples. 
sample in the natural state, and $k_{t}$ represents the susceptibility of samples demagnetized at temperature $\mathrm{t}\left({ }^{\circ} \mathrm{C}\right)$. The $k_{\mathrm{t}}$ and $k_{\mathrm{n}}$ values were measured on a kappa-bridge KLY-2 (Jelínek 1973).

The separation of the respective components of remanent magnetization was carried out using the multi-component analysis of Kirschvink (1980). The Fisher's statistics (1953) was used for a calculation of mean directions of components of the pertinent remanence derived by the multicomponent analysis.

\section{Palaeomagnetic results}

The principal petromagnetic parameters of 27 samples are summarized in Table 4 and Figure 8 for $1.75 \mathrm{~m}$ high sampled log.

Results of the multi-component analysis of the remanence (Kirschvink 1980) show that the samples from the Črnotiče Quarry display a three-component remanent magnetization. The $A$-component is undoubtedly of viscous (weathering) origin and can be demagnetized in a temperature range of 20 to $(60) 120^{\circ} \mathrm{C}$. The $B$-component also has a secondary origin but shows harder magnetic properties which can be demagnetized in a temperature range of about 120 to $360{ }^{\circ} \mathrm{C}$. The

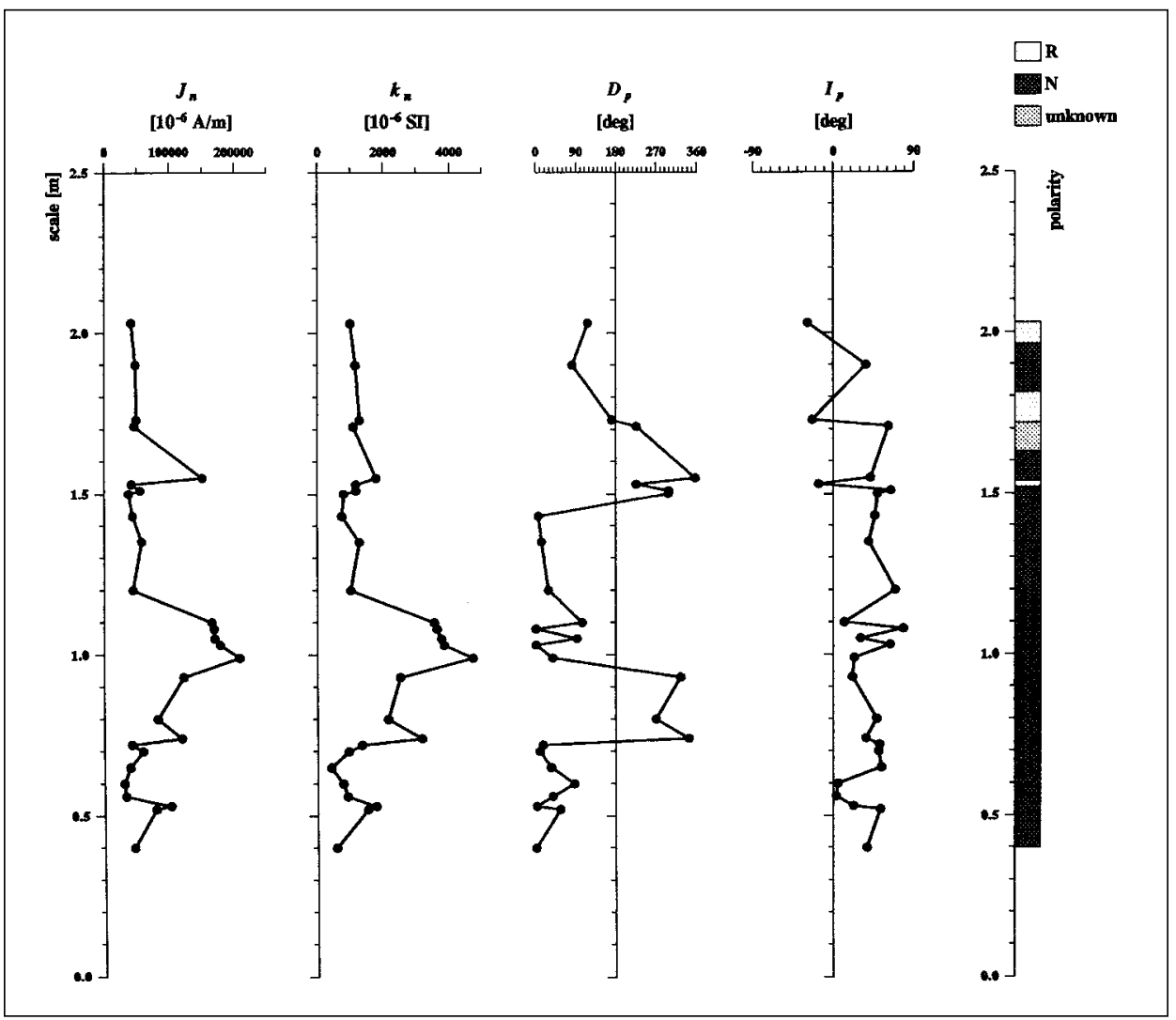

Fig. 8: Basic magnetic and magnetostratigraphic parameters of samples. 
C-component is the most stable, with demagnetization in a temperature range of about 400 to $560{ }^{\circ} \mathrm{C}$. The fisherian distribution forms two defined sets of samples with normal and reverse polarities. Stereographic projections of directions of normal and reverse palaeomagnetic Ccomponent in samples are shown in Fig. 9.

Mean direction RM are documented in Table 5, the calculated value of $\alpha_{95}$ (semi-vertical angle of the cone of confidence) is too big because the reverse group contains only three samples.

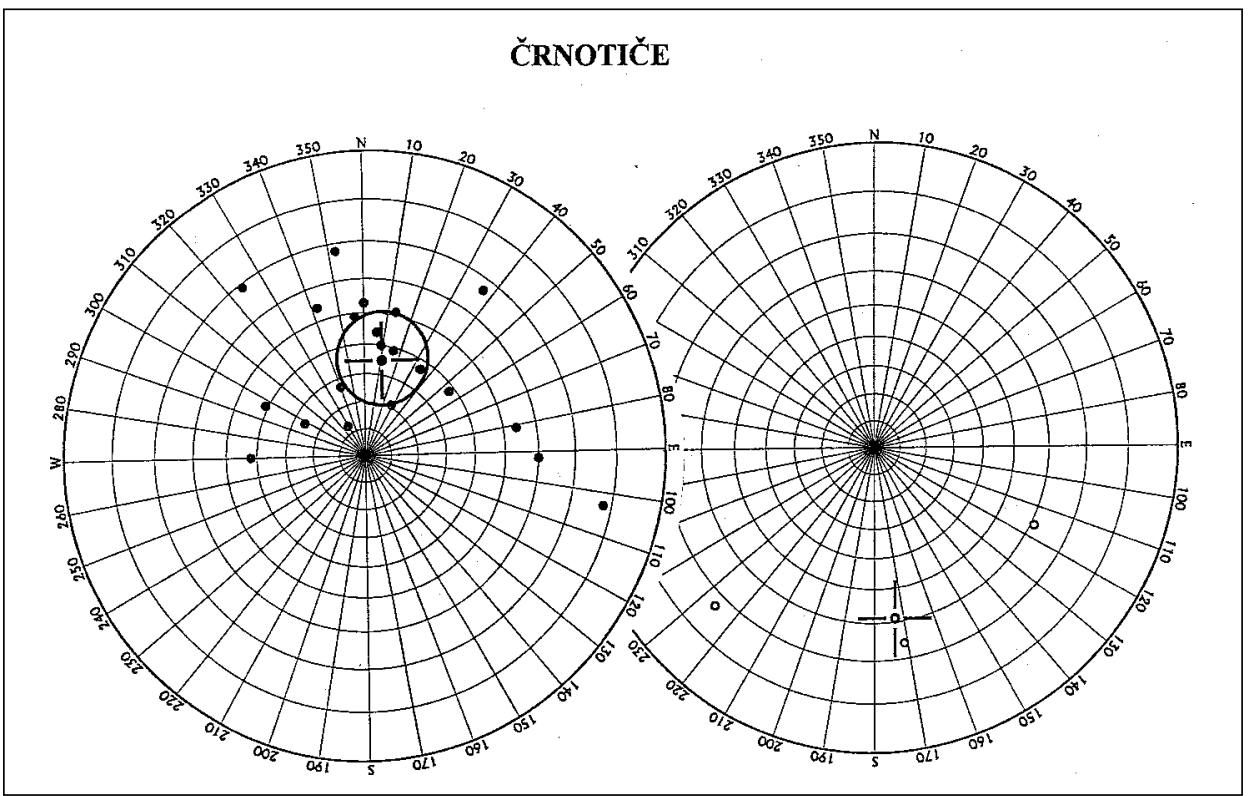

Fig. 9: Samples with normal (left side) and reverse (right side) of palaeomagnetic polarity. Stereographic projection, full (open) circles represent projection onto lower (upper) hemisphere. The mean direction calculated according to Fisher (1953) is denoted by a crossed circle, the confidence circle at the $95 \%$ probability level is circumscribed about the mean direction.

\begin{tabular}{|c|c|c|c|c|c|c|}
\hline \multirow{2}{*}{ Locality } & \multirow{2}{*}{ Polarity } & \multicolumn{2}{|c|}{$\begin{array}{c}\text { Mean palaeomagnetic } \\
\text { directions }\end{array}$} & \multirow{2}{*}{$\alpha_{95}$} & $\mathrm{k}$ & \\
\cline { 3 - 7 } & & $\mathrm{D} \mathrm{[{ } ^ { \circ } ]}$ & $\left.\mathrm{I} \mathrm{[}^{\circ}\right]$ & & & \\
\hline \multirow{2}{*}{ Crnotiče } & $\mathrm{N}$ & 10.6 & 55.0 & 15.8 & 5.0 & 21 \\
\cline { 2 - 7 } & $\mathrm{R}$ & 173.0 & -31.1 & 93.9 & 2.8 & 3 \\
\hline
\end{tabular}

Table 5: Mean palaeomagnetic directions.

Explanation: D, I - declination, inclination of the remanent magnetization after dip correction, $\alpha_{95}$ - semi-vertical angle of the cone of confidence calculated according to Fischer (1953) at the 95\% probability level, $k$ - precession parameter, $n$ - number of analyzed samples. 


\section{Magnetostratigraphic results}

Palaeomagnetic and magnetostratigraphic investigations carried out on 27 oriented laboratory samples of carbonate rocks yield data concerning principal magnetic properties and identification of palaeomagnetic directions:

(i) Preliminary data derived from pilot samples indicate that data suitable for multi-component analysis of remanence may be reliably derived and palaeomagnetic directions tested by thermal field of demagnetization on MAVACS apparatus,

(ii) Magnetostratigraphic investigations defined normal and reverse polarity magnetozones. In Figure 6, the black zone indicates normal polarity magnetozones; the white one shows reverse polarity magnetozones.

(iii) Obtained magnetostratigraphic results indicate also one unknown polarity.

(iv) The long normal magnetozone was interpreted in the lower half of the $1.75 \mathrm{~m}$ high log. The top part of the profile shows reverse palaeomagnetic direction interrupted by two normal magnetized zones.

\section{Discussion}

The arrangement of the distribution of normal and reverse polarity magnetozones within the Črnotiče log depends on abundant unconformities within the profile. We can estimate neither the duration of the deposition of banded carbonate body nor the duration of individual breaks in the deposition of carbonates. Two magnetozones are limited by such erosional surfaces, i.e. reverse polarized magnetozone of sample No. C153 at its base and normal polarized magnetozone of sample No. C190 at its top. It cannot be excluded that both magnetozones were in reality longer. Similarly, eight erosional surfaces detected within the lower normal polarized magnetozone (some breaks are represented by relatively thick layers of red clays) could hide eventual changes in the orientation of the magnetic field (polarization changes).

Therefore, the correlation with standard palaeomagnetic scales (Fig. 7) is problematic. Nevertheless, according to the arrangement of individual magnetozones in standard scales, we suppose that the top of the highest normal polarized magnetozone of our profile could be correlated with the top of the Olduvai event (1.76/1.79 Ma). This solution represents the youngest possibility; and the rest of profile must be therefore older.

\section{CONCLUSIONS}

A fossil cave in the Črnotiče Quarry yielded an about $1.75 \mathrm{~m}$ high profile of banded carbonate rocks intercalated by red clays deposited over corroded/eroded surface of older, highly recrystallized speleothems. Banded and laminated carbonate rocks are composed of slightly recrystallized calcilutite. Typical columnar texture of flowstones and other speleothems is missing, except of limited bands. Carbonate rocks resemble common limestones, rather than classical flowstones. Type of lamination could indicate its origin from organic-rich films (algal or diatom mats) on which fine carbonate grains were trapped of crystallised.

Red clays are composed of dominant quartz, smectite, vermiculite, gibbsite, pM kaolinite, goethite, anatase, rutile, haematite, calcite, micas and feldspar. Small pellets from washed clays have very similar composition plus relatively high amount of Mn hydroxyoxides (todorokite, $\mathrm{MnO}$ 


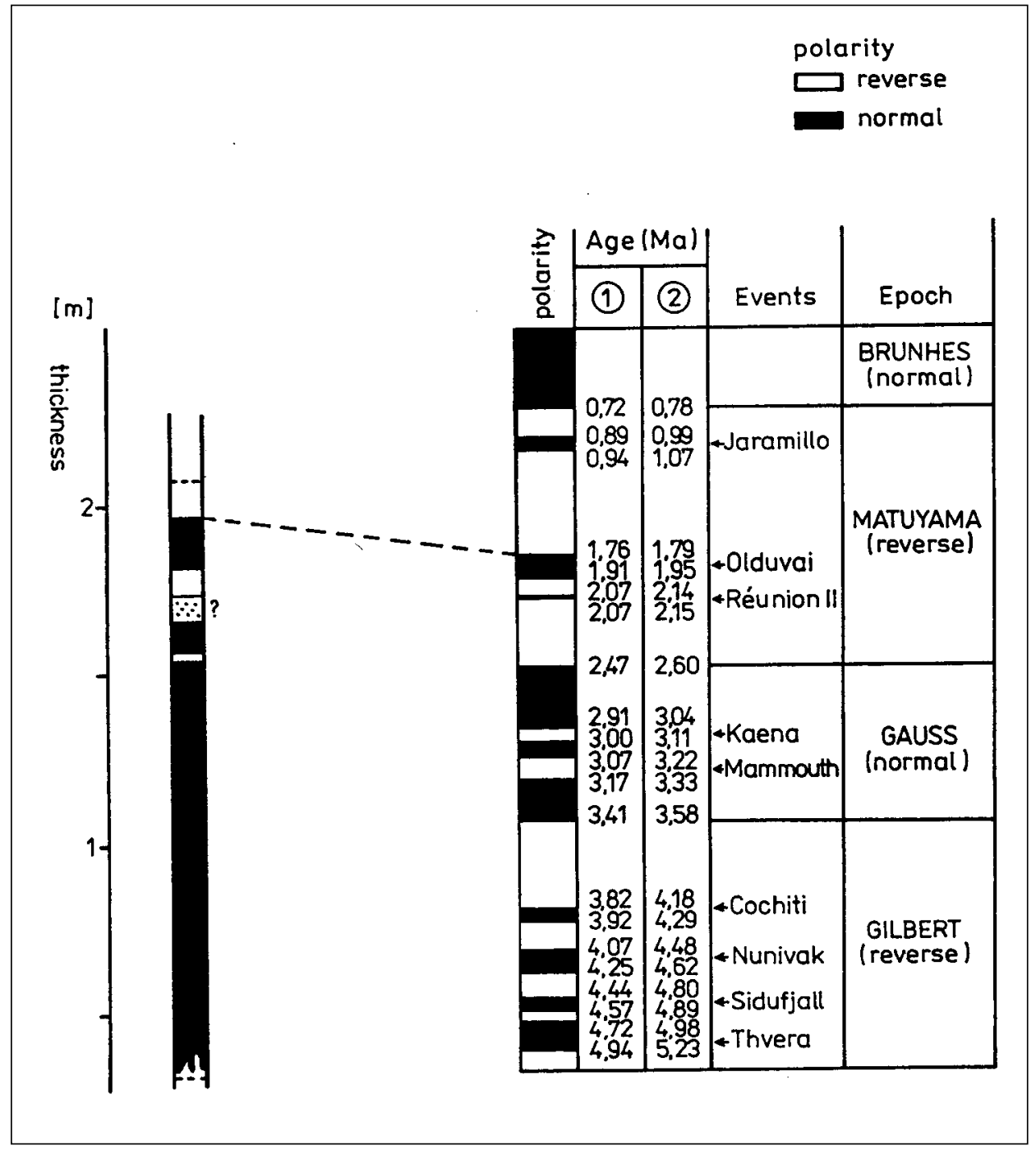

Fig. 10: Magnetostratigraphic data and correlation with geomagnetic polarity time scale for the Črnotiče profile. Palaeomagnetic scale according to Foucault and Raoult (1995), 1 - radiochronological data, 2 - data calibrated after the terrestrial orbit.

content is up to 68\%) and remarkable chromium content. Selective replacement by Mn or Al-rich mineral phases was detected within outer pellet zones (enrichment in kaolinite, gibbsite or todorokite). Chemical characteristics indicate that red clays are close to the terra rossa type of soils known from karst areas along the Adriatic Sea. Red clays represent redeposited weathering products of a terra 
rossa type. Most probably, red clays do not represent directly washed red soils, but reworked paludal deposits deposited from eroded weathering profiles both on limestones and flysch in watersaturated environment of lakes to marshes. Paludal sediments underwent an initial phase of bauxitisation (increased chromium content, indications of aluminium replacement of some of Mn-rich pellets and abundant gibbsite).

Samples are characterized by intermediate up to high magnetic values of $J_{n}=104.79 \pm 69.61$ [nT] and $k_{\mathrm{n}}=1778 \pm 1204.10^{-6}[\mathrm{SI}]$ as a consequence of a relatively high amount of iron-rich minerals (haematite, goethite). Mean palaeomagnetic directions are for the group of normal palaeomagnetic polarity equal to $\mathrm{D}=10.6^{\circ} ; \mathrm{I}=55.0^{\circ}$, and for the group of reverse polarity $\mathrm{D}=173.0^{\circ} ; \mathrm{I}=-31.3^{\circ}$.

Magnetostratigraphic investigations defined normal and reverse polarity magnetozones. Magnetostratigraphic results indicate also one unknown polarity. The long normal magnetozone was interpreted in the lower half of the log. The top part of the profile shows reverse palaeomagnetic direction interrupted by two normal magnetized zones. The arrangement of normal and reverse polarity magnetozones depends on abundant unconformities of unknown duration. The top of the highest normal polarized magnetozone of our profile could be correlated with the top of the Olduvai event (1.76/1.79 Ma) as the youngest possibility, as compared with the arrangement of individual magnetozones in a standard scales. Therefore, the rest of profile has to be older.

\section{ACKNOWLEDGEMENT}

We are grateful especially to the management of the Črnotiče Quarry for willing co-operation and permission for our operations within the quarry. Software for evaluation of palaeomagnetic measurements was prepared by Dr. Otakar Man, and samples for palaeomagnetic analyses were cut by Mr. Jakub Kanta (Department of Palaeomagnetism, Institute of Geology ASCR, PrahaPrühonice). Some figures were drawn by Mrs. Věra Havlíková and Mrs. Jana Rajlichová (Institute of Geology ASCR, Praha). Samples for the X-ray registration and evaluation were carefully prepared by Mr. Jiř́ Dobrovolný, and thin sections were produced by Mrs. Ivana Konopáčová (Service Laboratory of Physical Methods, Institute of Geology ASCR, Praha). Dr. Václav Cílek, Prof. Dr. Jaromír Ulrych, Prof. Dr. Jindřich Hladil, Dr. Anna Žigová (Institute of Geology, ASCR, Praha), and Prof. Dr. Ivan Horáček (Department of Biology, Charles Univ., Praha) are acknowledged for consultation concerning mineralogy, geochemistry, carbonate petrology, pedology and palaeontology. Prof. Dr. Rostislav Brzobohatý(Department of Geology and Palaeontology, Masaryk University, Brno) is acknowledged for his effort to determine faunal remains. Travel costs of Czech experts were covered from the program KONTAKT No. ME 251 of the Ministry of Education, Youth and Sports of the Czech Republic. Expenses of analytical procedures were covered from sources of the Program of Advancements in Scientific Research in Key Directions of the Academy of Sciences of the Czech Republic No. K1-042-603. The study was performed in the frame of the Czech scientific program No. Z3013912. 


\section{REFERENCES}

Aguilar J. P., J.Y. Crochet J.Y., Krivic K., Marandat B., Michaux J., Mihevc A., Šebela S. \& Sige B., 1998: Pleistocene small mammals from karstic fillings of Slovenia. - Acta Carsologica, 27/2: 141-150. Ljubljana.

Bárdossy G., 1982: Karst Bauxites. Bauxite Deposits on Carbonate Rocks. - Akademiai KiadóElsevier: 1-441. Budapest-Amsterdam.

Berger A., 1968: Zur Geochemie und Lagerstättenkunde des Mangan. - Clausthaler Hefte zur Lagerstättekunde und Geochemie der mineralischen Rohstoffe, 7: 1-216. Berlin-Stuttgart

Bosák P. Ed., 1984: Krasové jevy vrchu Turold u Mikulova. - Studie ČSAV, 5: 1-108. Praha.

Brodar S., 1958: Črni kal, nova paleolitska postaja v Slovenskem Primorju. - Razprave, IV: 269364. Ljubljana

Bushinsky G.I., 1971: Geologiya boksitov. - Nedra: 1-366. Moskva.

Fisher R., 1953: Dispersion on a sphere. - Proceedings of the Royal Society, A 217: 295-305. London.

Foucault A. \& Raoult J.-F. 1995: Dictionnaire de Géologie. 4 é Éd. - Masson: 1-324. Paris.

Harrassowitz H., 1926: Laterit. Material und Versuch erdgeschichtlicher Auswertung. - Fortschritte der Geologie und Paläontologie, 4, 14. Berlin.

Jelínek V., 1966: A high sensitivity spinner magnetometer. - Studia geophysica et geodetica, 10: 58 - 78. Praha.

Jelínek V., 1973: Precision A.C. bridge set for measuring magnetic susceptibility and its anisotropy. - Studia geophysica et geodetica, 17: 36 - 48. Praha.

Kirschvink J. L., 1980: The least-squares line and plane and the analysis of palaeomagnetic data. Geophysical Journal of the Royal Astronomical Society, 62: 699 - 718. Oxford.

Placer L., 1981: Geološka zgradba jugozahodne Slovenije. - Geologija, 24/1: 27-60. Ljubljana.

Příhoda K., Krs M., Pešina B. \& Bláha J., 1989: MAVACS - a new system of creating a nonmagnetic environment for palaeomagnetic studies. -Cuadernos de Geologica Ibérica, 12: 223 - 250. Madrid.

Rakovec I., 1958: Pleistocenski sesalci iz jame pri Črnem kalu. - Razprave, IV: 365-434. Ljubljana.

Weisse G. de, 1948: Les bauxites de l'Europe Centrale. - Mémoires de la Société Vaudoise de Science Naturelles, 58, 9: 1-162.

Zupan Hajna N., 1998: Mineral composition of clastic cave sediments and determination of their origin. - Kras i speleologia, 9 (XVIII): 169-178. Katowice. 


\section{PALEOMAGNETNE, MINERALOŠKE IN GEOKEMIČNE ANALIZE JAMSKIH SEDIMENTOV V KAMNOLOMU ČRNOTIČE}

\section{Povzetek}

V kamnolomu Črnotiče je bila izkopana okrog $150 \mathrm{~m}$ dolga fosilna jama. Njen $10 \mathrm{~m}$ visoki profil, ki je bil v celoti zapolnjen z jamskimi sedimenti, prodom, peskom, ilovico ter sigo so pri kopanju med leti 1990 do 1999 polagoma odstranili. V srednjem delu zapolnitve jame je bil analiziran okrog 1,75 m visok profil pasovite karbonatne kamnine z interkalacijami rdečih ilovic. Te kamnine so se odložile na erozijsko/korozijsko površino starejše, že močno prekristaljene sige, ki so jo prekrivale rdeče ilovice.

Pasovita in laminirana karbonatna kamnina je sestavljena iz nekoliko prekristaljenega kalcilutita. Tipične stebričaste teksture sige ali kapnikov so odsotne, razen izjemoma v omejenih pasovih. Karbonatna kamnina je bolj podobna običajnem sladkovodnem apnencu kot klasični sigi. Značilna laminiranost nakazuje njegov nastanek iz bogatih organskih filmov (diatomejskih ali algnih prevlek) na katere so se ujela ali rekristalizirala karbonatna zrna.

Rdeče ilovice sestavljajo kremen, ki prevladuje, smektit, vermikulit, gibbsit, pM kaolinit, goethit, atanas, rutil, haematit, kalcit, sljude in glinenec. Vsebujejo tudi majhne pelete s podobno sestavo, vendar večjim deležem Mn hidroksioksidov (todorokit, $\mathrm{MnO}$ več kot $68 \%$ ). Opazen je povečan delež kroma. Peleti imajo homogeno, mestoma pa koncentrično zgradbo. Z Mn ali Al minerali so bogate predvsem zunanje plasti peletov (obogatene so s kaolinitom, gibbsitom ali todorokitom).

Po kemijskih značilnostih so rdeče ilovice podobne terra rossi s krasa vzdolž Jadranske obale. Rdeče ilovice so presedimentirani ostanki preperevanja, vendar pa navzočnost Fe-Mn zrn in pa nekatera geokemična svojstva nakazujejo, da so rdeče ilovice vložene med karbonatne kamnine verjetno nastale iz starejših jezerskih sedimentov. Taki sedimenti so se odložili po eroziji preperine odložene bodisi na apnencu ali flišu v z vodo zasičenih okoljih kot so jezera ali močvirja. Jezerski sedimenti so prešli začetno fazo boksitizacije, kar nakazuje povečana vsebnost kroma, zamenjava aluminija v nekaterih z Mn bogatih zrnih ter obilje gibbsita.

Za vzete vzorce so značilne srednje do visoke vrednosti $J_{n}=104.79 \pm 69.61[\mathrm{nT}]$ in $k_{n}=1778 \pm 1204.10^{-6}[\mathrm{SI}]$ kar je posledica relativno velike količine železovih mineralov - (hematit, goethit). Srednja paleomagnetna smer je za skupino normalnih paleomagnetnih polaritet enaka $\mathrm{D}=10.6^{\circ} ; \mathrm{I}=55.0^{\circ}$, za skupino reverznih polaritet pa $\mathrm{D}=173.0^{\circ} ; \mathrm{I}=-31.3^{\circ}$.

$\mathrm{V}$ profilu smo z magnetostratigrafsko analizo določili magnetozone normalne in reverzne polaritete. Analize pa so pokazale tudi eno neznano polariteto. Spodnji del profila je bil odložen v času dolge normalne polariziranosti magnetnega polja. Zgornji del profila pa kaže reverzno paleomagnetno smer, ki jo prekinjata dve normalni magnetozoni.

Razporeditev in debelina normalnih in reverznih magnetozon je odvisna tudi od več hiatusev neznane dolžine profilu. Sodeč po razporeditvi posameznih magnetozon in primerjavo le teh s standardno skalo, lahko sklepamo, da je vrh najvišje normalno polarizirane cone v obravnavanem profilu primerljiv z dogodkom Olduvai (1.76/1.79 Ma) kot najmlajšo možnostjo, ostali del profila pa je lahko le starejši. 